\title{
A new genus of rhinebothriidean cestodes from batoid elasmobranchs, with the description of five new species and two new combinations
}

\author{
Florian B. Reyda ${ }^{1}$, Claire J. Healy ${ }^{2}$, Andrew R. Haslach ${ }^{3}$, Timothy R. Ruhnke ${ }^{3}$ Tara L. Aprill ${ }^{1}$, \\ Michael P. Bergman ${ }^{1}$, Andrew L. Daigler ${ }^{1}$, Elsie A. Dedrick ${ }^{1}$, Illari Delgado ${ }^{1}$, Kathryn S. Forti ${ }^{1}$, \\ Kaylee S. Herzog ${ }^{1}$, Rebecca S. Russell ${ }^{1}$ and Danielle D. Willsey ${ }^{1}$
}

\author{
${ }^{1}$ Biology Department \& Biological Field Station, State University of New York, College at Oneonta, Oneonta, New York, USA; \\ ${ }^{2}$ New Paltz, New York, USA; \\ ${ }^{3}$ Department of Biology, West Virginia State University, Institute, Virginia, USA
}

\begin{abstract}
Survey work of batoid elasmobranchs in the eastern Atlantic and Indo-Pacific revealed multiple species of a new genus of cestode. Stillabothrium Healy et Reyda gen. n. (Rhinebothriidea: Escherbothriidae) is unique in its possession of an even number of non-medial longitudinal septa in the posterior portion of the bothridia, resulting in a series of loculi that are longer than wide (i.e. vertically oriented) and are arranged in columns. Five new species of Stillabothrium are described, S. ashleyae Willsey et Reyda sp. n., S. davidcynthiaorum Daigler et Reyda sp. n., S. campbelli Delgado, Dedrick et Reyda sp. n., S. hyphantoseptum Herzog, Bergman et Reyda sp. n., S. jeanfortiae Forti, Aprill et Reyda sp. n., and two species are formally transferred to the genus, S. amuletum (Butler, 1987) comb. n., and S. cadenati (Euzet, 1954) comb. n., the latter of which is redescribed. The species differ in the configuration of the other bothridial septa and in proglottid anatomy. Species of Stillabothrium were found parasitising a total of 17 species of batoid elasmobranchs of the genera Dasyatis Rafinesque, Glaucostegus Bonaparte, Himantura Müller et Henle, Pastinachus Rüppell, Rhinobatos Linck and Zanobatus Garman, including several host species that are likely new to science. A phylogenetic hypothesis based on Bayesian analysis of 1084 aligned positions of the D1-D3 region of 28S rDNA for 27 specimens representing 10 species of Stillabothrium and two outgroup species supported the monophyly of Stillabothrium. These results also supported morphologically determined species boundaries in all cases in which more than one specimen of a putative species was included in the analysis. Host specificity appears to vary across species of Stillabothrium, with the number of host species parasitised by each species of Stillabothrium ranging from one to four. The geographic distribution of species of Stillabothrium spans the eastern Hemisphere, including the eastern Atlantic (coastal Senegal) and several locations in the Indo-Pacific (coastal Vietnam, Borneo and Australia). In addition, Phyllobothrium biacetabulatum Yamaguti, 1960 is formally transferred into family Escherbothriidae, although its generic placement remains uncertain (species incertae sedis).
\end{abstract}

Keywords: tapeworms, taxonomy, Rhinebothiidea, Escherbothriidae, Stillabothrium, stringrays, biodiversity, species boundaries

In recent years, global scale efforts to survey, inventory and describe tapeworms from vertebrates not previously examined for parasites have led to the discovery of hundreds of new species (Caira et al. 2012). Studies of newly collected material have also revealed new genera (Eyring et al. 2012, Schaeffner and Beveridge 2012, Jensen et al. 2014) and have facilitated recognition of new families (Ruhnke et al. 2015) and new orders (Kuchta et al. 2008, Healy et al. 2009, Caira et al. 2014) of cestodes.

The use of DNA sequence data has played a key role in these discoveries, but it also presents a new challenge in that the taxonomic treatments of new species often lag behind the publication of phylogenies that include such undescribed taxa. For example, in their proposal for the tapeworm order Rhinebothriidea, Healy et al. (2009) presented a phylogenetic hypothesis that included a total of 36 rhinebothriidean species, 27 of which were new to science, as well as four clades considered to represent new genera.

This paper focuses on species assigned to 'Rhinebothriinae New genus 3' by Healy et al. (2009). In addition to formal generic designation of Healy et al.'s (2009) New Genus 3, five new species are described and two described species are transferred to the new genus.

The present study includes a large collection of specimens of the new genus from Senegal, Malaysian Borneo, Indonesian Borneo, Vietnam and Australia. In a number of

Address for correspondence: F.B. Reyda, Biology Department \& Biological Field Station, State University of New York, College at Oneonta, Ravine Parkway Oneonta, NY, 13820-4015, USA. Phone: +1-607.436.3719; Fax: +1-607.436.3646; E-mail: florian.reyda@oneonta.edu

Zoobank number for article: urn:1sid:zoobank.org:pub:FE2205B0-4B03-4929-8177-FEA36E9D014D 
cases, determination of species boundaries based solely on morphological criteria was initially challenging. Sequence data for the partial 28S rDNA gene were therefore found to be of great use in helping to resolve species boundaries.

The present study contributes to a growing body of knowledge of elasmobranch cestodes by reporting on species of Rhinebothriinae New genus 3 from 17 species of elasmobranchs, nearly all of which have been reported as hosts for other cestode genera and species (see Euzet 1954, Butler 1987, Reyda and Caira 2006, Twohig et al. 2008, Ivanov and Caira 2012, Schaeffner and Beveridge 2012, 2014, Mojica et al. 2013, Cielocha et al. 2014, Jensen and Russell 2014, Jensen et al. 2014, Ruhnke et al. 2015). Most such reports are fairly recent and were the result of the same survey efforts that made the present study possible. Here we characterise a large amount of interspecific morphological variation, especially in bothridial morphology, among the seven species taxonomically treated here, emphasising the need for the continued application of molecular data in combination with morphological data for effectively delineating species.

\section{MATERIALS AND METHODS}

The cestode specimens examined here were obtained from a total of 38 elasmobranch specimens representing 17 species from the coasts of Senegal, Vietnam, Malaysian Borneo, Indonesian Borneo, and Australia. Elasmobranchs were collected by trawler, gill net, seine or bought directly from local fisherman or at fish markets. Each host was identified in the field, assigned a Collection Code and unique Collection Number, photographed and relevant information (e.g. sex, size) was recorded. A tissue sample was also collected for subsequent DNA analysis. Images and detailed collection data for each host can be accessed at the Global Cestode Database (Caira et al. 2012) at www.elasmobranchs.tapewormdb.uconn.edu by entering its assigned Collection Code and Collection Number (e.g. SE-289). Elasmobranch classification follows Naylor et al. (2012a); elasmobranch taxonomy follows Naylor et al. (2012b).

Host field identifications were verified using NADH2 sequence data for each host (see Naylor et al. 2012b). Hosts and their unique Collection Code and Collection Numbers obtained from each country are as follows: Rhinobatos rhinobatos (Linnaeus) (SE-289) and Zanobatus schoenleinii (Müller et Henle) (SE-28, SE-201, SE-299) from Senegal; Dasyatis zugei (Müller et Henle) (VN-23, VN-34) from Vietnam; Dasyatis biasa (Last, White et Naylor) (BO-477), Urogymnus lobistomus (Manjaji-Matsumoto et Last) (BO-247), Himantura cf. pastinacoides (BO-61, BO-79, BO-98, BO-100, BO-119, BO-168), Himantura uarnacoides (Bleeker) (BO-118), Himantura uarnak 3 (BO-47), Himantura undulata (Bleeker) (BO-24), Himantura heterura (Bleeker) (BO-19, BO-66, BO-67, BO-141, BO-170, BO-237, BO-238) and Pastinachus solocirostris Last, Manjaji et Yearsley (BO-267) from Malaysian Borneo; Dasyatis biasa (KA-182, KA-184, KA-378), Himantura macrura (Bleeker) (KA-111), Himantura gerrardi (Gray) (KA-145), Himantura oxyrhyncha (Sauvage) (KA-252), H. heterura (KA-99) and P. solocirostris (KA-148) from Indonesian Borneo; Himantura leoparda Manjaji-Matsumoto et Last (NT-117), Himantura australis Last, White et Naylor (CM03-3, CM03-25, CM03-65) and Glaucostegus ty- pus [Anonymous (Bennett)] (AU-56) from Australia. Additional locality data for each host are provided below in the relevant taxonomic treatment for each cestode species.

In the case of each host specimen, the spiral intestine was removed and opened with a longitudinal incision. A subsample of worms was removed, washed in seawater, and sorted into two sets. The first set was fixed in 10\% seawater-buffered formalin and subsequently stored in $70 \%$ ethanol, the other set was fixed in $95 \%$ ethanol. Spiral intestines were fixed in 10\% seawater-buffered formalin and additional worms were removed under a dissecting microscope upon returning to the laboratory. Worms to be prepared as whole mounts were hydrated in a graded series of ethanols, stained in Delafield's hematoxylin, destained in 70\% acid ethanol, neutralised in $70 \%$ basic ethanol, dehydrated in a graded ethanol series, cleared in methyl salicylate and mounted on glass slides in Canada balsam.

Specimens for histological sectioning were embedded in paraplast and sectioned at 8 or $10 \mu \mathrm{m}$ intervals using an Olympus CUT 4060 retracting rotary microtome. Sections were mounted on glass slides flooded with $2.5 \%$ sodium silicate and dried on a slide warmer for 4-8 hr. Cross sections of mature proglottids and longitudinal or cross sections of scoleces were prepared for each species described here. Sections were stained with Delafield's hematoxylin and eosin according to conventional techniques. A portion of each worm sectioned was prepared as a whole mount as described above, and retained as a voucher.

For examination with scanning electron microscopy (SEM), selected worms were first cut in half and the strobila of each worm was prepared as a whole mount, as above, and kept as a voucher and the scolex was examined with SEM. Scoleces were hydrated in a graded ethanol series, placed in 1\% osmium tetroxide overnight, dehydrated in a graded ethanol series, transferred to hexamethyldisilazane for $15 \mathrm{~min}$ in an exhaust hood and allowed to air dry. Dried worms were mounted on carbon tabs (Ted Pella, Inc., Redding, California) on aluminium stubs, placed in a dessicator overnight, sputter coated with 250-300 $\AA$ of gold/ palladium and examined with a LEO/Zeiss DSM982 Gemini or FEI Nova Nano 450 (University of Connecticut) field emission scanning electron microscope. Microthrix terminology follows Chervy (2009).

Measurements of whole mounted cestodes were obtained using an ocular micrometre on an Olympus CX31 compound microscope or taken with the aid of LAS V3.8 (Leica Application Suite, Leica microsystems, Switzerland) digital microscopy software connected to a Leica DSC295 digital camera on a Leica DM2500 compound microscope. All measurements are reported in micrometres, unless otherwise stated, and are provided in descriptions as the range followed in parentheses by the mean, standard deviation and number of worms measured. Scolex morphological shape terminology follows Clopton (2004). Drawings were made with the aid of a drawing tube. Museum abbreviations are as follows: IPCAS - Institute of Parasitology of the Biology Centre of the Czech Academy of Science, České Budějovice, Czech Republic; LRP - Lawrence R. Penner Parasitology Collection, Department of Ecology \& Evolutionary Biology, University of Connecticut, Storrs, Connecticut, USA; MNHN - Muséum National d'Histoire Naturelle, Paris, France; MZB - Museum Zooligum Bogoriense, Center for Biology, Indonesian Institute of Science, Cibinong, Jakarta-Bogo, Java, Indonesia; MZUM (P) - Muzium Zoologi, 
Universiti Malaya, Kuala Lumpur, Malaysia; QM, Queensland Museum, Queensland, Australia; SBC - Sarawak Biodiversity Center, Kuching, Sarawak, Malaysia; USNM - United States National Museum, Smithsonian Institution, Washington, D.C. USA. Nomenclatural acts in this manuscript are registered at Zoobank. org. Not all authors of this work are the authors of the individual generic and species descriptions. The authors of each individual taxonomic action are listed after the first use of the taxon name in the description.

Cestode specimens included in the molecular analyses, with taxon names, hosts, collection localities and museum voucher numbers for hologenophores, are provided in Table 1. Specimens for DNA sequencing that were originally fixed in $95 \%$ ethanol were digitally photographed using a Luminera Infinity 2 digital microscope camera on an Optivision SZ 6745 stereomicroscope. Digital images of those specimens were deposited in LRP. Scoleces and/or terminal proglottids were removed and prepared as whole mounts as described above and hologenophores (sensu Pleijel et al. 2008) were deposited in the LRP.

Total genomic DNA was extracted from the specimens using a Qiagen ${ }^{\circledR}$ DNEasy tissue kit. Kit protocol was followed with the following two exceptions: in the final elution of DNA, columns were allowed to stand for 15-20 min per elution, as opposed to one minute, and final elution was performed in nuclease free water as opposed to the kit buffer. The D1-D3 regions of the large nuclear ribosome regions (28S DNA) were amplified and sequenced using the forward primers ITS4f (5'-GCATATCAATAAGCGGAGGA-3'), LSU-5 (5'-TAGGTCGACCCGCTGAAYTTAAGC-3') and 330f (5'-CAAGTACCGTGAGGGAAAGTTG-3') and the reverse primers ECD2 (5'-CCTTGGTCCGTGTTTCAAGACGGG-3'), Tylo-1357 (5'-TCGATTTGCACGTCAGAATCG-3') and 1500R (5'-GCTATCCTGAGGGAAACTTCG-3'). The D1-D3 region of 28S rDNA was amplified using Promega ${ }^{\circledR}$ GoTaq Master Mix (Promega Corp., Madison, Wisconsin, USA) in a Bio$\operatorname{rad}^{\circledR}$ iCycler version 4006 (Bio-Rad Laboratories, Inc., Hercules, California, USA) under the following conditions: denaturation at $95^{\circ} \mathrm{C}$ for $30 \mathrm{~s}$, annealing at $52^{\circ} \mathrm{C}$ for $30 \mathrm{~s}$, and extension at $72{ }^{\circ} \mathrm{C}$ for $2 \mathrm{~min} 30 \mathrm{~s}$, repeated for 45 cycles. PCR amplicons were loaded into a $1 \%$ molecular grade agarose gel with $1 \mathrm{X}$ TAE buffer. Gels were stained using ethidium bromide and were visualised using a FluorChem ${ }^{\mathrm{TM}} 8900$ system (Protein Simple, San Jose, California, USA) as well as an ultra violet lamp tray. Bands of the correct length were excised and purified using a Promega Wizard $^{\circledR}$ SV Gel and PCR Clean-Up System. Kit protocol was followed with one exception: final incubation time with elution buffer was extended from $1 \mathrm{~min}$ to $15-30 \mathrm{~min}$ DNA yield was analysed for yield by gel electrophoresis. DNA was sequenced using ABI Big Dye 3.1v chemistry.

Sequencing product was cleaned using EDTA/ethanol precipitation and analysed by an ABI 3130x/genetic analyser. Contiguous sequences of $28 \mathrm{~S}$ rDNA were assembled using or Geneious 6.1.5. Alignments were performed using the Muscle option in MEGA v. 6. Sequences were aligned with MUSCLE in Geneious v. 5.6.4 with default settings. Phylogenetic analyses were conducted on sequences from a total of 27 cestode specimens, including 19 specimens from which sequences were generated de novo for this study (Table 1). Anthocephalum michaeli Ruhnke et Seaman, 2009 and Escherbothrium sp. were used as outgroup species.
Bayesian inference was conducted using MrBayes version 3.2 (Ronquist and Huelsenbeck 2003) with the following setttings: lset $n s t=6$ rates $=$ invgamma ngammacat $=4$; ngen $=5000000$; samplefreq $=1000$. Fifty percent of the samples were discarded on burnin. A parsimony bootstrap analysis was also conducted using PAUP* version 5.4.0b (Swofford 2000). One thousand replicates $(1000)$ were performed, with 10 step-wise 6 addition heuristic searches per replicate.

\section{RESULTS}

Phylogenetic analyses. The Bayesian phylogram topology is given in Fig. 1. Strong support for the monophyly of replicate specimens of each species of Stillabothrium gen. n. was found both as a result of the Bayesian and Bootstrap analyses. The ten species of Stillabothrium gen. n. were grouped in two principle clades, each with five species. Clade 1 (see Fig. 1) consisted of Stillabothrium jeanfortiae sp. n., Stillabothrium cadenati (Euzet, 1954) comb. n., and three undescribed species (Stillabothrium spp. n. 1, 2, 4). Four of these five species conspicuously lack marginal septa on the posterior region of the bothridia, but the scolex voucher (LRP 3899) of the fifth species, Stillabothrium sp. n. 2, bears marginal septa in the anterior region of the bothridia that appear to extend into the posterior region. Clade 2 comprises Stillabothrium amuletum (Butler, 1987) comb. n., Stillabothrium hyphantoseptum sp. n., Stillabothrium ashleyae sp. n., Stillabothrium davidcynthiaorum sp. n., and Stillabothrium campbelli sp. n. Four of the five species of that clade possess marginal septa in the posterior region of the bothridia, in contrast, $S$. hyphantoseptum sp. n., does not (Fig. 1).

The results of the phylogenetic analyses also provide support for the morphologically-based species boundaries employed here. For each species of Stillabothrium gen. n. for which two or more specimens were sequenced (i.e. S. ashleyae sp. n., S. davidcynthiaorum sp. n., S. campbelli sp. n., S. hyphantoseptum sp. n., S. cadenati [Euzet, 1954] comb. n.), the replicate specimens of morphologically circumscribed species were found to be monophyletic (Table 1, Fig. 1). However, among the five species, only the three replicates of $S$. ashleyae sp. n. (all from KA-182) were identical with one another. Two samples of $S$. davidcynthiaorum sp. n. from two different stingray species (KA145.3 from $H$. gerrardi and KA-111.1 from Himantura macrura) differed by one base pair (bp) from one another, as well as from the four specimens from $H$. heterura (BO237.1, BO-237.2, BO-237.3, and LRP 3926), and from the single specimen from Himantura uarnak 3 (BO-47.2). All four specimens of $S$. campbelli sp. n. were obtained from the same individual Himantura cf. pastinacoides. One of those four specimens (BO-100.8) differed by one bp from the other three. The two specimens of S. hyphantoseptum sp. n. (KA-148.1, KA-148.3), both from the same individual $P$. solocirostris, differed by two bp. Two specimens of S. cadenati comb. n. (SE-299.1, SE-299.2), both from the same individual of $Z$. schoenleinii, differed from one another by one bp. One of those (SE-299.1) was identical to a specimen (LRP 3924) from another individual of 
Table 1. Cestode specimens included in the molecular analyses, with taxon names, hosts, localities, field and specimen codes, museum voucher numbers for hologenophores and GenBank numbers.

\begin{tabular}{|c|c|c|c|c|c|c|c|}
\hline Species $\dagger$ & Host species & Locality & Field code & $\begin{array}{l}\text { Specimen } \\
\text { number }\end{array}$ & $\begin{array}{l}\text { Voucher } \\
\text { Acc. No. }\end{array}$ & $\begin{array}{l}\text { GenBank } \\
\text { Acc. No.** }\end{array}$ & References \\
\hline $\begin{array}{l}\text { Anthocephalum michaeli } \\
\text { Ruhnke et Seaman, } 2009\end{array}$ & $\begin{array}{l}\text { Dasyatis longa } \\
\text { (Garman) }\end{array}$ & $\begin{array}{l}\text { Gulf of California, San Jose del } \\
\text { Cabo, Mexico }\end{array}$ & BJ-423 & BJ-423 & LRP 8515 & KM658204 & $\begin{array}{l}\text { Ruhnke et al. } \\
2015\end{array}$ \\
\hline Escherbothrium sp. & Urotrygon sp. 1 & $\begin{array}{l}\text { Eastern Pacific Ocean, Costa } \\
\text { Rica }\end{array}$ & CRP-50 & CRP-50 & LRP 8519 & KM6 & $\begin{array}{l}\text { Ruhnke et al. } \\
2015\end{array}$ \\
\hline $\begin{array}{l}\text { Stillabothrium amuletum } \\
\text { (Butler, 1987) comb. n.* }\end{array}$ & Glaucostegus typus & $\begin{array}{l}\text { Timor Sea, off Dundee Beach, } \\
\text { Northern Territory, Australia }\end{array}$ & AU-56 & AU-56 & LRP 3917 & FJ177117 & $\begin{array}{l}\text { Healy et al. } \\
2009\end{array}$ \\
\hline \multirow{3}{*}{$\begin{array}{l}\text { Stillabothrium ashleyae } \\
\text { Willsey et Reyda sp. } \mathrm{n} \text {. }\end{array}$} & \multirow{3}{*}{$\begin{array}{l}\text { Dasyatis biasa } \\
\text { (Last, White et Naylor) }\end{array}$} & \multirow{3}{*}{$\begin{array}{l}\text { Java Sea (Pacific Ocean), off } \\
\text { Selakau, West Kalimantan, Indo- } \\
\text { nesian Borneo }\end{array}$} & KA-182 & KA-182.3 & LRP 8992 & KX826838 & Present study \\
\hline & & & KA-182 & KA-182.4 & LRP 8993 & KX826837 & Present study \\
\hline & & & KA-182 & KA-182.5 & LRP 8994 & KX826836 & Present study \\
\hline \multirow[t]{4}{*}{$\begin{array}{l}\text { Stillabothrium cadenati } \\
\text { (Euzet, 1954) comb. n. }\end{array}$} & $\begin{array}{l}\text { tos rhinobatos } \\
\text { s) }\end{array}$ & $\begin{array}{l}\text { Eastern Atlantic Ocean, off } \\
\text { Kafountine, Senegal }\end{array}$ & SE-289 & SE-289.1 & LRP 9000 & KX826839 & Present study \\
\hline & \multirow{3}{*}{$\begin{array}{l}\text { Zanobatus schoenleinii } \\
\text { (Müller et Henle) }\end{array}$} & & & & 001 & & tudy \\
\hline & & & & & 002 & $\mathrm{KX}$ & $\operatorname{Pr}$ \\
\hline & & $\begin{array}{l}\text { Eastern Atlantic Ocean, off Sou- } \\
\text { mbedioune, Senegal }\end{array}$ & SE-201 & SE-201 & LRP 3924 & FJ177110 & $\begin{array}{l}\text { Healy et al. } \\
2009\end{array}$ \\
\hline \multirow{4}{*}{$\begin{array}{l}\text { Stillabothrium campbelli } \\
\text { Delgado, Dedrick et Reyda } \\
\text { sp. n. }\end{array}$} & \multirow{4}{*}{$\begin{array}{l}\text { Himantura cf. pastina- } \\
\text { coides }\end{array}$} & \multirow{4}{*}{$\begin{array}{l}\text { Sulu Sea (Pacific Ocean), off } \\
\text { Kampung Tetabuan, Sabah, } \\
\text { Malaysian Borneo }\end{array}$} & & .2 & 995 & $\mathrm{KX}$ & Present study \\
\hline & & & & & & & \\
\hline & & & 00 & & 97 & & $\operatorname{Pr}$ \\
\hline & & & & & & & \\
\hline \multirow{7}{*}{$\begin{array}{l}\text { Stillabothrium david- } \\
\text { cynthiaorum Daigler et } \\
\text { Reyda sp. } \mathrm{n} \text {. }\end{array}$} & \multirow{3}{*}{$\begin{array}{l}\text { Himantura heterura } \\
\text { (Bleeker) }\end{array}$} & \multirow{3}{*}{$\begin{array}{l}\text { South China Sea, off Mukah, } \\
\text { Sarawak, Malaysian Borneo }\end{array}$} & & 7.1 & 986 & K) & Pre \\
\hline & & & 37 & $\mathrm{BC}$ & 87 & $\mathrm{~K} 2$ & tudy \\
\hline & & & & $\mathrm{BO}$ & 988 & KX826849 & Present study \\
\hline & Himantura heterura & $\begin{array}{l}\text { Sout } \\
\text { Sara }\end{array}$ & BO-237 & BO-237 & LRP 3926 & FJ177116 & $\begin{array}{l}\text { Healy et al. } \\
2009\end{array}$ \\
\hline & Himantura uarnak 3 & $\begin{array}{l}\text { South China Sea, } \\
\text { Sarawak, Malays }\end{array}$ & BO-47 & $\mathrm{BO}-$ & LRP 8989 & KX826851 & Present study \\
\hline & $\begin{array}{l}\text { Himantura macrura } \\
\text { (Bleeker) }\end{array}$ & $\begin{array}{l}\text { Java Sea (Pacific Ocean), off } \\
\text { Kalapseban, Central Kalimantan, } \\
\text { Indonesian Borneo }\end{array}$ & -111 & KA-111.1 & LRP & KX82 & Pre \\
\hline & $\begin{array}{l}\text { Himantura gerrardi } \\
\text { (Gray) }\end{array}$ & $\begin{array}{l}\text { Java Sea (Pacific Ocean), off } \\
\text { Singkawang, West Kalimantan, } \\
\text { Indonesian Borneo }\end{array}$ & 145 & KA-145.3 & LRP 8991 & KX826850 & Present study \\
\hline \multirow{2}{*}{$\begin{array}{l}\text { Stillabothrium hyphanto- } \\
\text { septum Herzog, } \\
\text { Bergman et Reyda sp. n. }\end{array}$} & \multirow{2}{*}{$\begin{array}{l}\text { Pastinachus solocirostris } \\
\text { Last, Manjaji et Yearsley }\end{array}$} & \multirow{2}{*}{$\begin{array}{l}\text { Java Sea (Pacific Ocean), off } \\
\text { Singkawang, West Kalimantan, } \\
\text { Indonesian Borneo }\end{array}$} & 48 & & 003 & 853 & Pre \\
\hline & & & & & & & Pres \\
\hline $\begin{array}{l}\text { Stillabothrium jeanfortiae } \\
\text { Forti, Aprill et Reyda sp. } n \text {. }\end{array}$ & \multicolumn{2}{|c|}{$\begin{array}{l}\text { Himantura australis Last,Gulf of Cerpentaria, Weipa, } \\
\text { White et Naylor } \quad \text { Australia }\end{array}$} & $\mathrm{CMO} 3-3$ & CMO3-3.5 & LRP 8999 & KX826854 & Present study \\
\hline Stillabothrium sp. n. $1 \dagger$ & $\begin{array}{l}\text { Fontitrygon margari- } \\
\text { tella } \$ \text { (Compagno et } \\
\text { Roberts) }\end{array}$ & $\begin{array}{l}\text { Eastern Atlantic Ocean, off } \\
\text { Mbour, Senegal }\end{array}$ & SE-125 & SE-125 & LRP 3898 & FJ177111 & $\begin{array}{l}\text { Healy et al. } \\
2009\end{array}$ \\
\hline Stillabothrium sp. n. $2 \dagger$ & $\begin{array}{l}\text { Fontitrygon margari- } \\
\text { tella } \$\end{array}$ & $\begin{array}{l}\text { Eastern Atlantic Ocean, off } \\
\text { Mbour, Senegal }\end{array}$ & SE-125 & SE-125 & LRP 3899 & FJ177112 & $\begin{array}{l}\text { Healy et al. } \\
2009\end{array}$ \\
\hline Stillabothrium sp. n. $4 \dagger$ & $\begin{array}{l}\text { Himantura astra } \$ \text { Last, } \\
\text { Manjaji-Matsumoto et } \\
\text { Pogonoski }\end{array}$ & $\begin{array}{l}\text { Wessel Islands, Arafura Sea, } \\
\text { Australia }\end{array}$ & NT-26 & NT-26 & LRP 3906 & FJ177114 & $\begin{array}{l}\text { Healy et al. } \\
2009\end{array}$ \\
\hline
\end{tabular}

$\dagger$ undescribed rhinebothriine species follow the naming scheme used by Healy et al. (2009); $\$$ denotes hosts that were previously referred to under different names by Healy et al. (2009); * referred to by Healy et al. (2009) as Rhinebothriinae New genus 3 n. sp. 7; ** (D1-D3 28S rDNA).

the same host species, Z. schoenleinii. The other specimen (SE-299.2) was identical to a specimen (SE-289.1) from a different host species, $R$. rhinobatos.

Stillabothrium Healy et Reyda gen. n.

ZooBank number for genus:

urn:1sid:zoobank.org:act:B2B660B1-E30D-4208-935E-F89C06A2D16D

Diagnosis: Rhinebothriidea. Worms euapolytic, small. Scolex consisting of scolex proper and 4 bothridia; cephalic peduncle absent; short germinative zone present; apical organ absent. Bothridia stalked, consisting of anterior and posterior regions with distinctly different arrangement of loculi and septa; bothridial margins with thin rim. Anterior region with horizontally oriented loculi (i.e. loculi wider than long) with two (Figs. 2B, 4B) or more (Figs. 6B, 8B, 10B, 12B, 15) complete transverse septa, with (Figs. 2B, $4 \mathrm{~B}$ ) or without (Figs. 6B, 8B, 10B, 12B, 15) single partial medial longitudinal septum. Posterior region lacking medial longitudinal septum, divided into odd number of vertically oriented loculi (i.e. loculi longer than wide) by even number of nonmedial longitudinal septa; nonmedial longitudinal septa all incomplete (Figs. 6B, 8B, 10B, 12B, 15) or a combination of incomplete and complete (Figs. 2B, 4B); incomplete nonmedial longitudinal septa either abut posteriormost transverse septum of anterior region of bothridia (Figs. 2B, 4B, 10B,), or overlap one or more posteriormost transverse septa (Figs. 6B, 8B, 12B, 15). Lateral margins of posterior region of bothridium divided into additional loculi by marginally (Figs. 2B, 4B) or diagonally (Figs. 6B, 15) oriented septa in some species. 


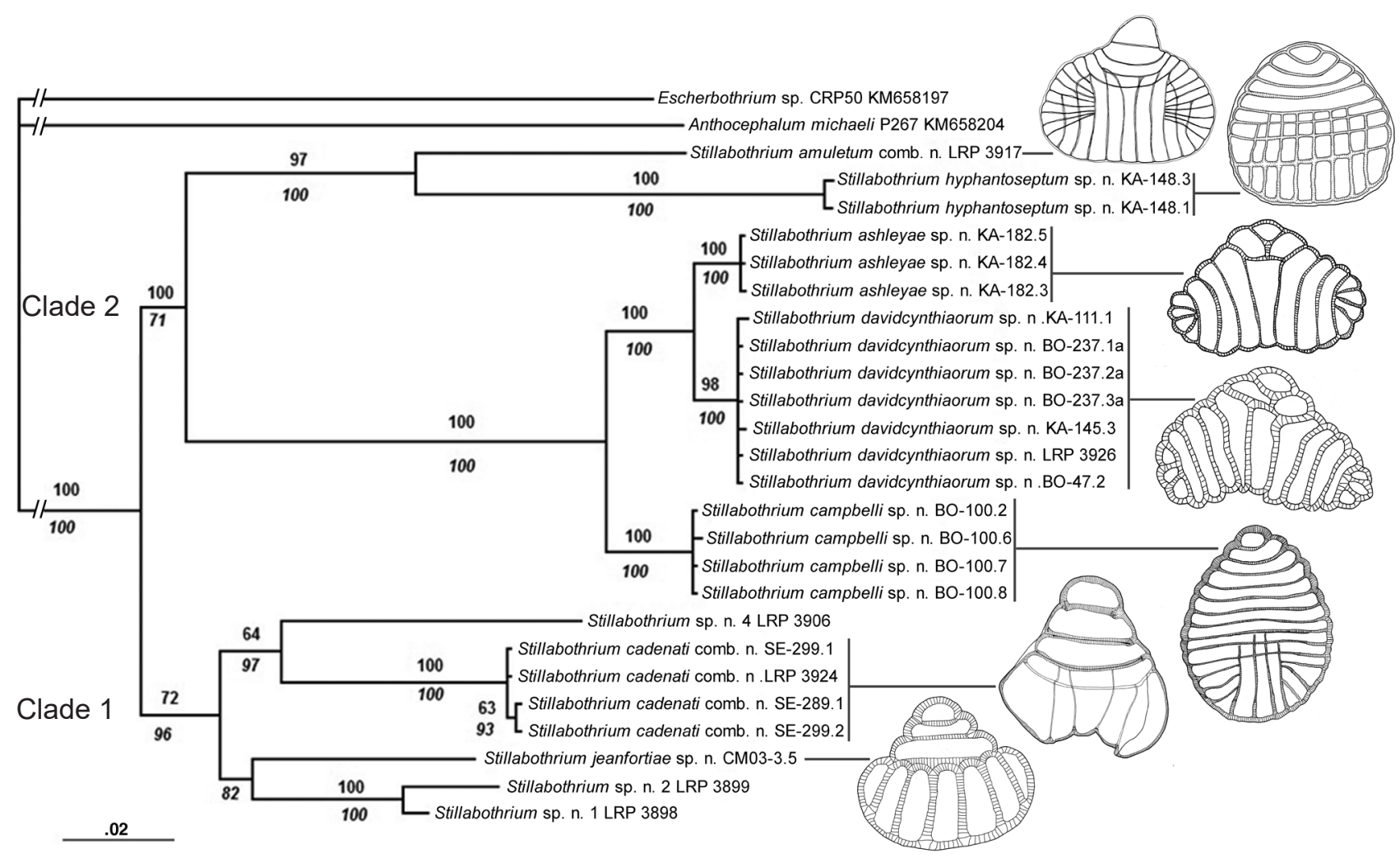

Fig. 1. Phylogram based on Bayesian analysis of 1084 bp region of D1-D3 28S rDNA. Numbers above branches indicate Bayesian posterior probabilities, numbers below indicate Bootstrap percentage values, based on 1000 replicates. Scale indicates expected number of substitutions per site. Diagrammatic line drawings of fully opened bothridia of the seven described species mapped onto the clades representing those respective species. Host species information in Table 1.

Longitudinal septa of posterior region appear as ridges in section (Fig. 13) with proximal and distal portions different; proximal portion of septa formed by underlying bothridial wall, consisting of radial muscles oriented with proximal ends of fibres adjacent to each other; distal portion of septa formed by separate muscle bundle; proximal and distal portions of septa separated by triangular gap.

Testes numerous, arranged in two columns, one layer deep in cross section, restricted to pre-poral region of proglottid. Cirrus sac extending medially to or past midline of proglottid. Cirrus spinitriches present. Vas deferens extending posteriorly to ovarian isthmus, entering cirrus sac at anterior margin. Vagina opening anterior to cirrus sac; vaginal sphincter absent. Ovary H-shaped in dorsoventral view, tetralobed in cross section. Vitellarium follicular; follicles in 2 lateral bands; bands interrupted by terminal genitalia and usually also by ovary. Uterus saccate, medial, extending from posterior margin of proglottid or ovarian isthmus, anteriorly to near anterior margin of proglottid. Parasites of batoid elasmobranchs (Rhinobatidae, Zanobatidae and Dasyatidae); Indo-Pacific and coastal Afro-tropics.

Informal synonyms: Rhinebothriinae New genus 3 Healy et al. (2009), Caira et al. (2014), Ruhnke et al. (2015), and Marques and Caira (2016).

Type species: Stillabothrium ashleyae sp. n.

Additional species: Stillabothrium amuletum (Butler, 1987) comb. n.; Stillabothrium cadenati (Euzet, 1954) comb. n.; Stillabothrium campbelli sp. n.; Stillabothrium davidcynthiaorum sp. n.; Stillabothrium hyphantoseptum sp. n.; Stil- labothrium jeanfortiae sp. $\mathrm{n}$.

Etymology: From the Latin 'stilla', meaning drop, for the teardrop shape of the bothridia of species the genus.

Remarks. Stillabothrium gen. n. is generally consistent with the diagnosis of the order Rhinebothriidea as given by Healy et al. (2009): Species of Stillabothrium possess facially loculated bothridia borne on stalks and possess a vas deferens that enters the cirrus sac at the anterior, rather than the medial, margin. Stillabothrium can be distinguished from all rhinebothriidean genera except Escherbothrium Berman and Brooks, 1994, Phormobothrium Alexander, 1963 and Tritaphros Lönnberg, 1889 in its possession of bothridia that are fully facially loculate, with posterior loculi that are longer than wide. Stillabothrium differs from Phormobothrium and Tritaphros in lacking an apical organ on the scolex. Stillabothrium is most similar to Escherbothrium, but Stillabothrium can be distinguished from the latter genus in lacking a medial longitudinal septum in the posterior region of the bothridium, thereby possessing an odd number of loculi. In Escherbothrium, the posterior region of the bothridium includes a short medial longitudinal septum (see fig. 6 in Berman and Brooks 1994) and an even number of loculi. In addition, Escherbothrium was described as possessing an apical sucker and rounded protrusions on its distal bothridial surfaces (see both in fig. 8 in Berman and Brooks 1994). Conversely, in Stillabothri$u m$ the feature on the anteriormost portion of the bothridium is considered to be a loculus, rather than a sucker, and 
no rounded protrusions were observed on the scolex of any surfaces of any of the six species of Stillabothrium examined with SEM in this study. Based on the recent designation of families within Rhinebothriidea by Ruhnke et al. (2015), Stillabothrium belongs to family Escherbothriidae Ruhnke, Caira et Cox, 2015.

Species of Stillabothrium have appeared in previous works under different temporary names. The genus was first recognised by Healy (2006) in her dissertation, under a preliminary name which, as recommended by Article 8 of the ICZN (1999), she disclaimed. In addition to providing preliminary morphological characterisation of species, Healy (2006) included partial 28S rDNA sequence data for eight species of Stillabothrium. Subsequently, four molecular phylogenetic studies (Healy et al. 2009, Caira et al. 2014, Ruhnke et al. 2015, Marques and Caira 2016) have included the sequence data originally generated by Healy (2006). Each study, which refers to Stillabothrium as 'Rhinebothriinae New genus 3', supported recognition of those eight species as an independent, novel, genus.

Stillabothrium ashleyae Willsey et Reyda sp. n.

Figs. 1-3, 16A

ZooBank number for species:

urn:lsid:zoobank.org:act:B316EE69-A04B-4A09-9AB5-658752FDC431

Description (based on whole mounts of 25 complete mature worms and 14 free proglottids, cross sections of 2 strobila, longitudinal sections of 1 scolex, and 3 scoleces prepared for SEM): Worms (Fig. 2A) euapolytic, acraspedote, $1.11-2.78 \mathrm{~mm}(1.66 \pm 0.39 ; \mathrm{n}=23)$ long, greatest width $353-590(455 \pm 70 ; n=24)$ at level of scolex; 6-10 (7.7. $\pm 1 ; \mathrm{n}=25)$ proglottids per worm. Cephalic peduncle lacking; darkly staining germinative zone 17-217 (54 \pm 37 ; $\mathrm{n}=24$ ) long.

Scolex (Fig. 2B) consisting of scolex proper bearing 4 stalked bothridia. Stalks 46-164 (76 $\pm 31 ; n=13)$ long by 53-100 (75 $\pm 17 ; \mathrm{n}=13)$ wide, attached slightly posterior to middle of bothridia. Bothridia (Fig. 2B) varying in shape with degree of contraction, from shallowly-deltoid (Fig. 3A) to deeply-deltoid (Fig. 3B), facially loculated, 140-227 $(175 \pm 26 ; n=20)$ long by $190-334(270 \pm 44$; $\mathrm{n}=24$ ) wide; bothridial margins with thin rim. Anterior region of bothridia (Fig. $2 \mathrm{~B})$ with $3(\mathrm{n}=18)$ horizontally oriented loculi (i.e. loculi wider than long) with 2 complete transverse septa and one partial medial longitudinal septum. Anteriormost loculus 30-46 $(39 \pm 5 ; \mathrm{n}=15)$ long by $41-72(59 \pm 11 ; n=18)$ wide. Posterior region of bothridia with $8(\mathrm{n}=21)$ nonmedial longitudinal septa dividing bothridia into 9 primary loculi longer than wide; outermost primary loculi on each side subdivided by 3 , or occasionally $2(2.94 \pm 0.2 ; \mathrm{n}=16)$ relatively short marginal septa into 3-4 small subloculi; longitudinal septa of posterior region not overlapping transverse septa of anterior region.

Loculi (Fig. 3D) and septa of distal bothridial surfaces bearing capilliform filitriches and coniform spinitriches. Proximal bothridial rim (Fig. 3E) bearing capilliform filitriches greater in length than those on distal bothridial sur- faces (Fig. 3D). Proximal bothridial surfaces (Fig. 3E,F) away from rim bearing acicular filitriches and coniform spinitriches. Isolated cilia observed on proximal bothridial surfaces. Bothridial stalks (Fig. 3G) and strobila (Fig. 3H) bearing capilliform filitriches only.

Strobila with 2-4 $(3.2 \pm 0.8 ; \mathrm{n}=25)$ proglottids wider than long followed by $3-7(4.5 \pm 1 ; n=25)$ proglottids longer than wide. Strobila widest at terminal proglottid; terminal proglottid 320-880 (591 $\pm 125 ; \mathrm{n}=25)$ long by $68-150(101 \pm 20 ; n=24)$ wide; genital pore located $35-46 \%(40 \pm 3 ; n=25)$ of proglottid length from proglottid posterior margin. Immature proglottids 4-9 (6.4 \pm 1.2 ; $\mathrm{n}=25)$ in number. Mature proglottids $1-2(1.2 \pm 0.4$; $\mathrm{n}=25)$ in number, including $0-1(0.3 \pm 0.5 ; \mathrm{n}=25)$ vas deferens-mature proglottids.

Testes in mature proglottids $18-27(22 \pm 2 ; \mathrm{n}=25)$ in total number, 1 layer deep in cross section (Fig. 2D), arranged in 2 columns (Fig. 2C); columns extending from anterior margin of proglottid to anterior margin of cirrus sac, $19-37(25 \pm 4 ; \mathrm{n}=24)$ long by $20-45(31 \pm 6 ; \mathrm{n}=22)$ wide. Vas deferens coiled, entering anterior margin of cirrus sac, extending from level of ovarian isthmus to overlap posteriormost testes (Fig. 2C). Cirrus sac thin-walled, oval, extending medially to near midline of proglottid; cirrus sac in terminal mature proglottid 26-42 $(33 \pm 5 ; \mathrm{n}=17)$ long by $26-47(32 \pm 6 ; \mathrm{n}=17)$ wide; cirrus sac in vas deferens-mature proglottids $28-38(34 \pm 4 ; \mathrm{n}=8)$ long by $36-50$ $(43 \pm 5 ; n=8)$ wide. Cirrus spinitriches present.

Vagina (Fig. 2C) thick-walled, weakly sinuous, somewhat overlapping anterior margin of cirrus sac (Fig. 16A), extending along midline of proglottid from ootype region to anterior margin of cirrus sac, then laterally to open into genital atrium anterior to cirrus sac; vaginal sphincter absent. Seminal receptacle present. Ovary near posterior end of proglottid, H-shaped in frontal view, tetralobed in cross section (Fig. 2E); ovarian lobes asymmetrical; poral and aporal ovarian lobes in terminal mature proglottids $80-215(161 \pm 33 ; \mathrm{n}=16)$ and $85-220(163 \pm 34 ; \mathrm{n}=16)$ long, respectively. Poral and aporal ovarian lobes in vas deferens-mature proglottids 146-265 (194 $\pm 47 ; \mathrm{n}=7)$ and 141-282 (190 $\pm 51 ; \mathrm{n}=7)$ long, respectively. Maximum width of ovary 35-96 (56 $\pm 17 ; \mathrm{n}=17)$. Ovarian isthmus at or anterior to midpoint of ovary; poral lobe of ovary stopping 26-63 (41 $\pm 12 ; \mathrm{n}=23)$ short of genital pore. Mehlis' gland well posterior to ovarian isthmus, 19-35 $(26 \pm 5 ; \mathrm{n}=21)$ long by $14-30(18 \pm 4 ; \mathrm{n}=21)$ wide. Vitellarium follicular; vitelline follicles arranged in 1 dorsal and 1 ventral column on each side of proglottid; columns extending from anterior to posterior margin of proglottid, interrupted by terminal genitalia, and mostly interrupted by ovary (Fig. 2C). Uterus ventral, sacciform, extending from near isthmus of ovary to near anterior margin of proglottid.

Free proglottids with greatly expanded vas deferens and atrophied testes, 521-919 (724 $\pm 136 ; \mathrm{n}=12)$ long by 134-202 $(165 \pm 21 ; \mathrm{n}=12)$ wide. Free gravid proglottids $750(n=1)$ long by $210-280(245 \pm 50 ; n=2)$ wide; unembryonated eggs oval, without filaments, 14-17 (15 \pm 1 ; $\mathrm{n}=6$; from same proglottid) long. 


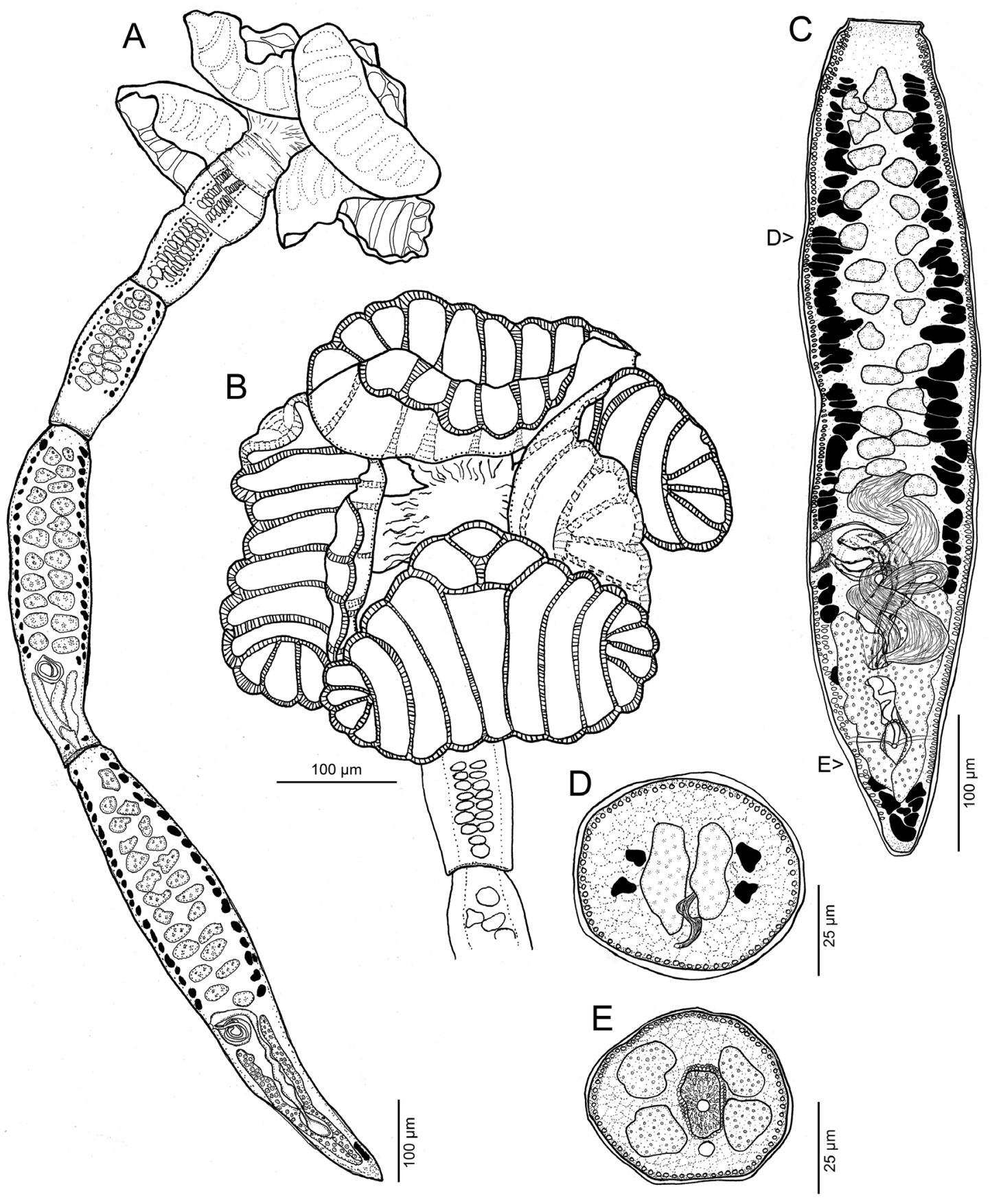

Fig. 2. Line drawings of Stillabothrium ashleyae sp. n. from Dasyatis biasa (Last, White et Naylor). A - whole worm (holotype; MZUM [P] 2016.6 [H]); B - scolex (LRP 9011); C - terminal proglottid (LRP 9010) with position of sections labeled (uterus not shown); D - section of mature proglottid at level of testes (LRP 9037); $\mathbf{E}$ - section of mature proglottid posterior to ovarian bridge (LRP 9030).

Type host: Dasyatis biasa (Last, White et Naylor) (Myliobatiformes: Dasyatidae).

Additional host: None.

Type 1ocality: South China Sea off Mukah $\left(02^{\circ} 53^{\prime} 52^{\prime \prime N}\right.$; $\left.112^{\circ} 05^{\prime} 44^{\prime \prime E}\right)$, Sarawak, Malaysian Borneo (BO-477).

A d d it i o nal 1 o c a liti e s : Java Sea off Selakau $\left(01^{\circ} 03^{\prime} 31^{\prime \prime N}\right.$; 108 58'26"E), West Kalimantan, Indonesian Borneo (KA-182, KA-184). Java Sea off Sukadana (0114'33"S; 10957'00"E), West Kalimantan, Indonesian Borneo (KA-378).

Site of infection: Spiral intestine.

Type material: Holotype MZUM(P) No. 2016.6(H). Paratypes: IPCAS No. C-737; LRP Nos. 8992-8994; 9005-9037 (including molecular vouchers, cross sections and SEM specimens); MZB Nos. Ca197-Ca199; MZUM (P) Nos. 2016.7 (P)-2016.8 (P); SBC No. P-00069; USNM Nos. 14204531420460 .

Etymology: This species is named in honour of Ashley Willsey Attoma, sister of D.D. Willsey, for her support of her sister's studies.

Remarks. Stillabothrium ashleyae sp. n. is the type and first described species of the genus. The distribution of $S$. ashleyae includes both the Malaysian and Indonesian portions of the island of Borneo. Stillabothrium ash- 

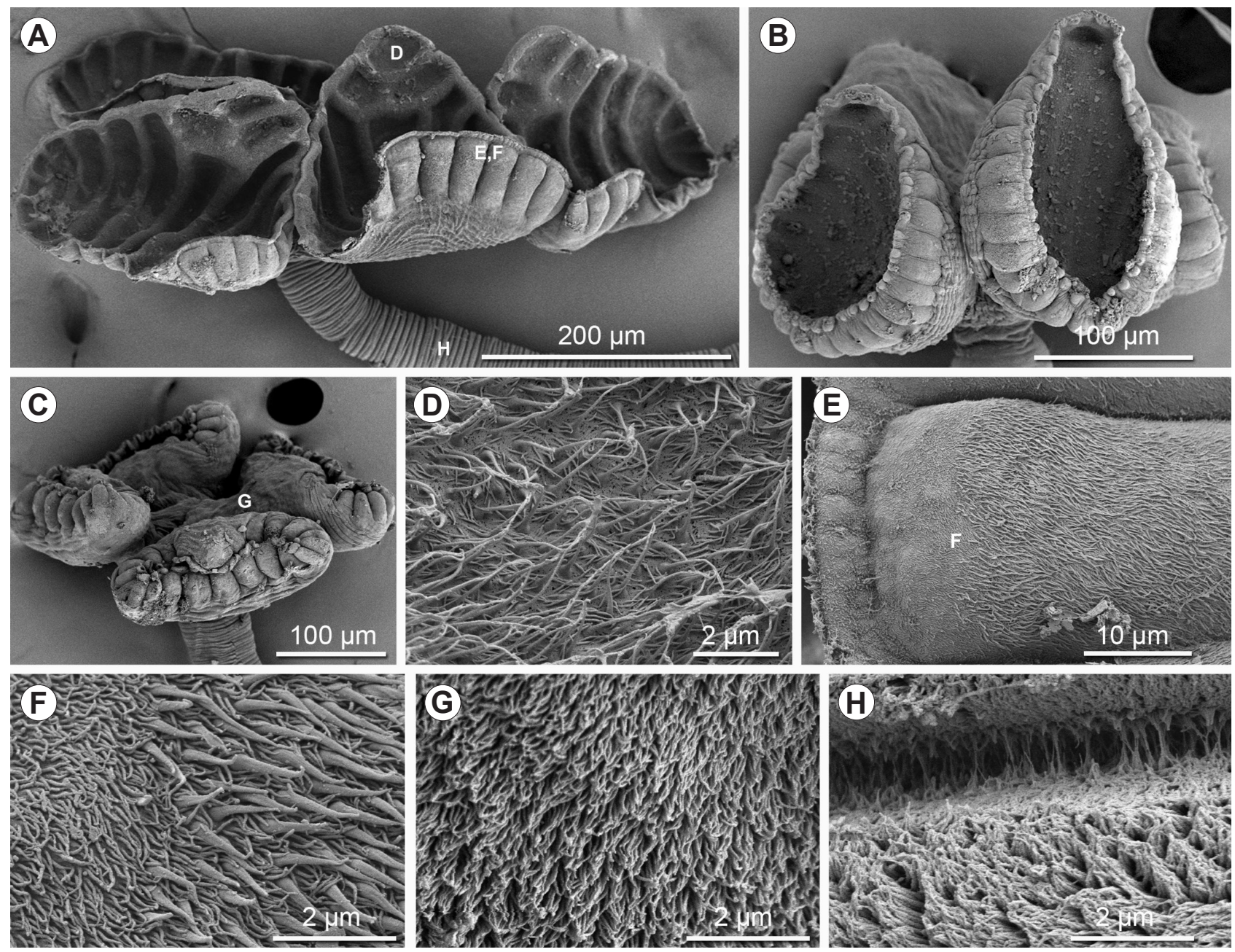

Fig. 3. Scanning electron micrographs of Stillabothrium ashleyae sp. n. from Dasyatis biasa (Last, White et Naylor). A-C - scoleces, letters indicate locations of other SEMs; D - distal bothridial surface at anterior loculus; E - proximal bothridial surface and rim, letter indicates location of F; F - proximal bothridial surface; $\mathbf{G}$ - stalk; $\mathbf{H}$ - strobila.

leyae appears to be highly host specific, as it was only encountered in specimens of D. biasa. It was not found parasitising any of the multiple other species of dasyatids (e.g. Dasyatis Rafinesque and Himantura Müller et Henle) examined during our survey work. We note that specimens with a morphology similar to $S$. ashleyae were found in D. zugei (VN-23, VN-34) from Vietnam. However, preliminary molecular and morphological data suggest that the specimens from Vietnam represent a distinct species of Stillabothrium that awaits formal study and description.

Three specimens of $S$. ashleyae were included in the phylogenetic analysis (Fig. 1, Table 1).

Stillabothrium davidcynthiaorum Daigler et Reyda sp. n. Figs. 1, 4, 5, 16B

ZooBank number for species:

urn:Isid:zoobank.org:act:D36AE2D9-C4A6-4C4D-8F82-E9C0FAF1F92C

Description (based on whole mounts of 32 complete mature worms, cross sections of 1 strobila and longitudinal sections of 1 scolex and 3 scoleces prepared for SEM): Worms (Fig. 4A) euapolytic, acraspedote, 0.62-2.59 mm
$(1.29 \pm 0.57 ; \mathrm{n}=30)$ long, greatest width 195-561 $(332 \pm 84.7 ; \mathrm{n}=32)$ at level of scolex; $4-10(7 \pm 2.1 ; \mathrm{n}=32)$ proglottids per worm. Cephalic peduncle lacking; darkly staining germinative zone $12-40(22 \pm 7 ; \mathrm{n}=29)$ long.

Scolex (Fig. 4B) consisting of scolex proper bearing 4 stalked bothridia. Stalks $25-100(52 \pm 20 ; n=23)$ long by $27-83(55 \pm 17 ; \mathrm{n}=23)$ wide, attached slightly posterior to middle of bothridia. Bothridia (Fig. 4B) varying in shape with degree of contraction, from shallowly-deltoid (Fig. 5A) to deeply-deltoid (Figs. 4B, 5B), facially loculated, $72-175(108 \pm 26 ; n=20)$ long by $140-325(202 \pm 42$; $\mathrm{n}=32$ ) wide; bothridial margins with thin rim. Anterior region of bothridia (Fig. 4B) with $3(n=28)$ horizontally oriented loculi (i.e. loculi wider than long) with 2 complete transverse septa and one partial medial longitudinal septum. Anteriormost loculus 22-49 (31 $\pm 8 ; \mathrm{n}=18)$ long and 37$78(47 \pm 9 ; n=25)$ wide. Posterior region of bothridia with $10(\mathrm{n}=30)$ nonmedial longitudinal septa dividing bothridia into 11 primary loculi longer than wide, outermost primary loculi on each side subdivided by 2 , or occasionally 3 $(2.04 \pm 0.2 ; n=24)$ relatively short marginal septa into 3-4 small subloculi; longitudinal septa of posterior region not overlapping transverse septa of anterior region. 

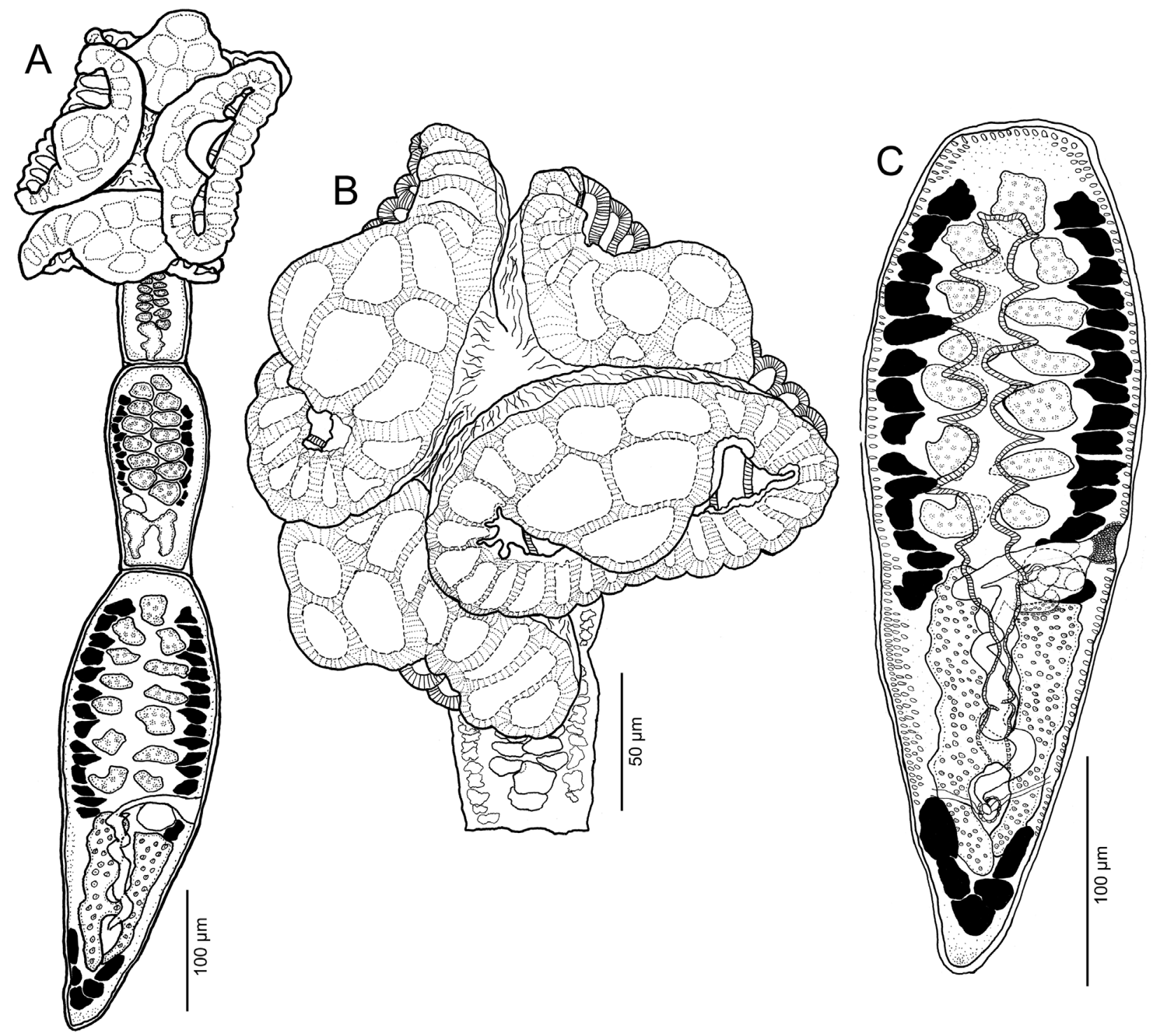

Fig. 4. Line drawings of Stillabothrium davidcynthiaorum sp. n. from Himantura heterura (Bleeker). A - whole worm (LRP 9046); B - scolex (holotype, MZUM [P] 2016.9 [H]); C - terminal proglottid (LRP 9046).

Loculi and septa of distal bothridial surfaces (Fig. 5C) bearing capilliform filitriches and coniform spinitriches. Proximal bothridial rim (Fig. 5D) bearing capilliform filitriches greater in length than those on distal bothridial surfaces (Fig. 5C). Proximal bothridial surfaces (Fig. 5D,E) away from rim bearing acicular filitriches and coniform spinitriches. Isolated cilia observed on proximal bothridial surfaces. Bothridial stalks (Fig. 5F) bearing capilliform filitriches and coniform spinitriches; strobila (Fig. 5G) bearing capilliform filitriches only.

Strobila with $1-5(2.6 \pm 0.9 ; \mathrm{n}=32)$ proglottids wider than long followed by $2-8(4.1 \pm 1.8 ; \mathrm{n}=32)$ proglottids longer than wide. Strobila widest at terminal proglottid; terminal proglottid $255-790(438 \pm 124 ; \mathrm{n}=31)$ long by $60-144(108 \pm 18 ; \mathrm{n}=32)$ wide; genital pore located $42-54 \%(48 \pm 3.5 ; \mathrm{n}=21)$ of proglottid length from proglottid posterior margin. Immature proglottids 3-9 $(5.5 \pm 1.9 ; \mathrm{n}=32)$ in number. Mature proglottids $1-3$ $(1.2 \pm 0.5 ; \mathrm{n}=32)$ in number, including $0-2(0.2 \pm 0.5$; $\mathrm{n}=32$ ) vas deferens-mature proglottids.
Testes in mature proglottids $11-21(16 \pm 3 ; \mathrm{n}=32)$ in total number, 1 layer deep in cross section, arranged in 2 columns (Fig. 4C); columns extending from anterior margin of proglottid to anterior margin of cirrus sac, 13-49 $(25 \pm 8 ; \mathrm{n}=32)$ long by $24-50(35 \pm 6 ; \mathrm{n}=32)$ wide. Vas deferens coiled, entering anterior margin of cirrus sac, extending from level of ovarian isthmus to overlap posteriormost testes. Cirrus sac thin-walled, oval, extending medially to near midline of proglottid; cirrus sac in terminal mature proglottid 18-35 (26 $\pm 5 ; \mathrm{n}=26)$ long by $24-38$ ( $31 \pm 4 ; \mathrm{n}=24)$ wide; cirrus sac in vas deferens-mature proglottids 32-45 $(39 \pm 5 ; \mathrm{n}=5)$ long by 33-46 $(40 \pm 5$; $\mathrm{n}=5$ ) wide. Cirrus spinitriches present.

Vagina (Fig. 4C) thick-walled, weakly sinuous, somewhat overlapping anterior margin of cirrus sac (Fig. 16B), extending along midline of proglottid from ootype region to anterior margin of cirrus sac, then laterally to open into genital atrium anterior to cirrus sac; vaginal sphincter absent. Seminal receptacle present. Ovary near posterior end of proglottid, $\mathrm{H}$-shaped in frontal view, tetralobed in 

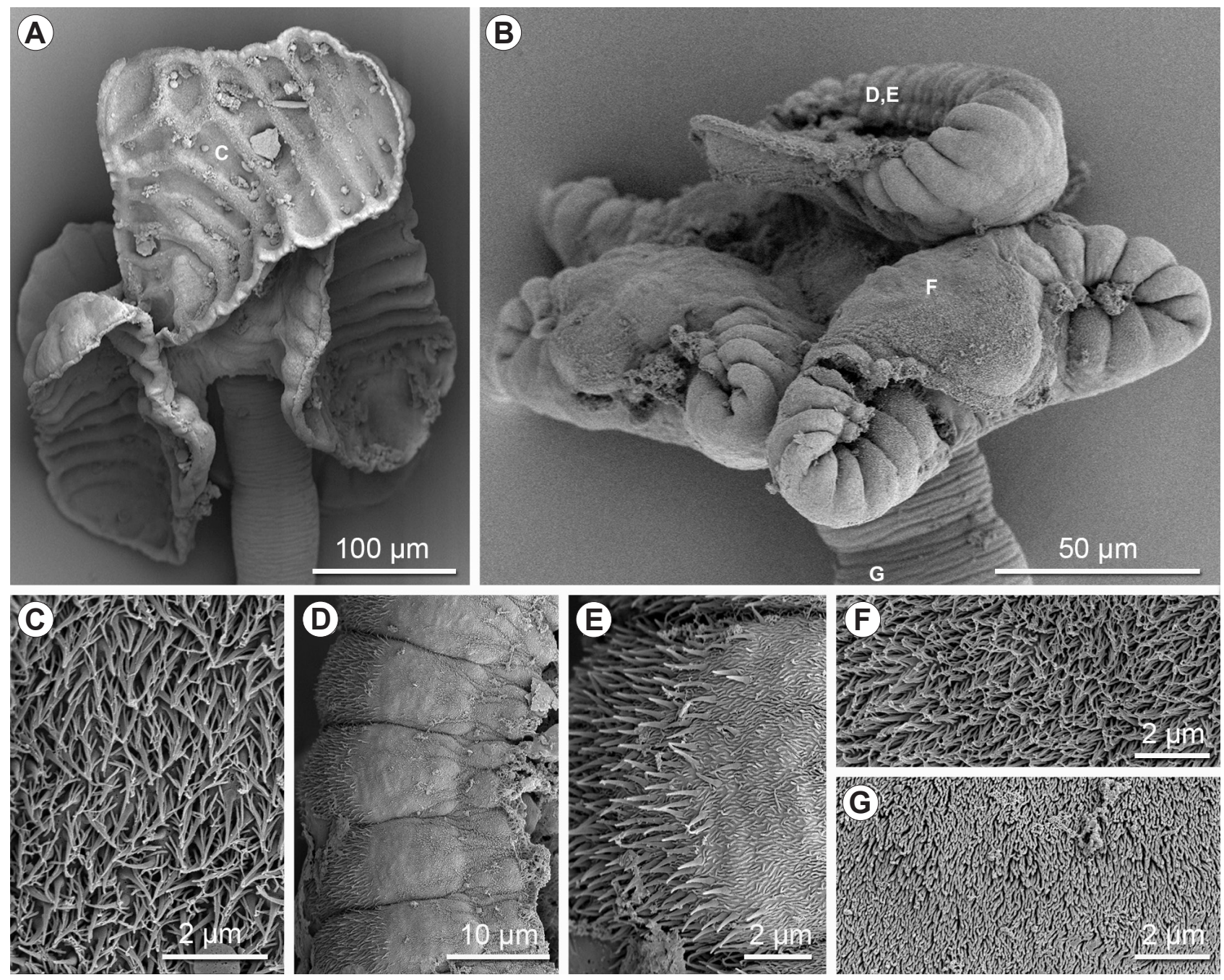

Fig. 5. Scanning electron micrographs of Stillabothrium davidcynthiaorum sp. n. from Himantura uarnak 3 (A, C, F) and Himantura heterura (Bleeker) (B, D, E, G). A, B - scoleces, letters indicate locations of other SEMs; C - distal bothridial surface in center of loculus; D - proximal bothridial surface with rim; $\mathbf{E}$ - proximal bothridial surface near rim; F - proximal bothridial surface; $\mathbf{G}$ - strobila.

cross section; ovarian lobes asymmetrical; poral and aporal ovarian lobes in terminal mature proglottids $75-254$ $(144 \pm 40 ; \mathrm{n}=24)$ and $75-272(152 \pm 42 ; \mathrm{n}=24)$ long, respectively. Poral and aporal ovarian lobes in vas deferens-mature proglottids $145-269(198 \pm 48 ; \mathrm{n}=5)$ and $152-270(206 \pm 46 ; n=5)$ long, respectively. Maximum width of ovary $39-139(65 \pm 21 ; n=32)$. Ovarian isthmus near midpoint of ovary; poral lobe of ovary stopping 19-85 (31 $\pm 16 ; \mathrm{n}=28)$ short of genital pore. Mehlis' gland well posterior to ovarian isthmus, $12-43(27 \pm 8 ; \mathrm{n}=29)$ long by $10-35(20 \pm ; n=29)$ wide. Vitellarium follicular, vitelline follicles arranged in 1 dorsal and 1 ventral column on each side of proglottid; columns extending from anterior to posterior margin of proglottid, interrupted by genital genitalia, and mostly interrupted by ovary (Fig. 4C). Uterus ventral, sacciform, extending from near isthmus of ovary to near anterior margin of proglottid.

Informal synonyms: Rhinebothriinae New genus $3 \mathrm{sp}$. n. 6 of Healy et al. (2009), Caira et al. (2014), Ruhnke et al. (2015), Marques and Caira (2016).

Type host: Himantura heterura (Bleeker), dwarf whipray
(Myliobatiformes: Dasyatidae).

Additional hosts: Himantura macrura, Himantura gerrardi, Himantura uarnak 3.

Type 1 oc a lity: South China Sea off Sematan $\left(01^{\circ} 48^{\prime} 15^{\prime \prime N}\right.$; $109^{\circ} 46^{\prime} 47^{\prime \prime E}$ ), Sarawak, Malaysian Borneo (hosts BO-19, BO141, BO-170).

Additional localities: South China Sea off Mukah (0253'52"N; $\left.112^{\circ} 05^{\prime} 44^{\prime \prime} \mathrm{E}\right)$, Sarawak, Malaysian Borneo (BO-47, BO-66, BO-67, BO-237, BO-238). Java Sea off Kalapseban $\left(03^{\circ} 14^{\prime} 30^{\prime \prime} \mathrm{S}\right.$; $\left.112^{\circ} 54^{\prime} 52^{\prime \prime E}\right)$, Central Kalimantan, Indonesian Borneo (KA-99, KA-111). Java Sea off Singkawang $\left(00^{\circ} 55^{\prime} 06^{\prime \prime} \mathrm{N}\right.$; $\left.108^{\circ} 58^{\prime} 60^{\prime \prime} \mathrm{E}\right)$, West Kalimantan, Indonesian Borneo (KA-145).

Site of infection: Spiral intestine.

Type materia 1: Holotype MZUM(P) No. 2016.9(H). Paratypes: IPCAS No. C-739; LRP Nos. 8986-8991; 9038-9062 (including molecular vouchers, cross sections and SEM specimens); MZB Nos. Ca200-Ca201; MZUM (P) No. 2016.10 (P); SBC No. P-00070; USNM Nos. 1420461-1420466.

Etymology: This species is named in honour of David and Cynthia Daigler, parents of A.L. Daigler, for their support of his education and his interests. 
Remarks. Stillabothrium davidcynthiaorum sp. n. can be distinguished from $S$. ashleyae in its possession of 10 , rather than eight, longitudinal septa on the central posterior region of the bothridium. While $S$. davidcynthiaorum and $S$. ashleyae are similar in possessing a range of 2-3 marginal septa on both of the lateral sides on the posterior region of the bothridium, the former differs from the latter in mean number $(2.04[\mathrm{n}=24]$ vs $2.94[\mathrm{n}=16])$.

In the present study we report specimens of $S$. davidcynthiaorum from potentially four species of Himantura, H. heterura, H. macrura, H. gerrardi and H. uarnak 3. Although $S$. davidcynthiaorum was encountered in four potential species of Himantura, we point out having encountered specimens morphologically similar to $S$. davidcynthiaorum in four additional species of Himantura that were examined during the survey work in Borneo, including Himantura cf. pastinacoides (BO-61, BO-168), H. undulata (BO-24), U. lobistomus (BO-247) and H. oxyrhyncha (KA-252). Further examination of the Stillabothrium specimens from those additional four species of Himantura is needed, in combination with DNA sequence data, to establish whether those cestodes are conspecific with S. davidcynthiaorum or represent an undescribed species of the genus.

Seven specimens of $S$. davidcynthiaorum were included in the phylogenetic analysis (Fig. 1, Table 1). One of the seven specimens (LRP 3926) was previously included in the analysis provided by Healy et al. (2009) as 'Rhinebothriinae New genus 3 sp. n. 6'.

Stillabothrium campbelli Delgado, Dedrick et Reyda sp. n. Figs. 1, 6, 7, 16C

ZooBank number for species:

urn:1sid:zoobank.org:act:8EA1CC15-6A59-4FDC-96DE-7B8389B40F7C

Description (based on whole mounts of 14 complete mature worms, cross sections of 2 strobila and longitudinal sections of 3 scoleces and 3 scoleces prepared for SEM): Worms (Fig. 6A) euapolytic, acraspedote, 1.06-2.60 mm $(1.68 \pm 0.4 ; \mathrm{n}=14)$ long, greatest width $170-360(261 \pm 55$; $\mathrm{n}=14)$ at level of scolex; 5-8 $(6 \pm 1.0 ; \mathrm{n}=14)$ proglottids per worm. Cephalic peduncle lacking; small darkly staining germinative zone present.

Scolex (Fig. 6B) consisting of scolex proper bearing 4 stalked bothridia. Stalks 20-90 (49 $\pm 2 ; \mathrm{n}=13)$ long by $25-110(68 \pm 25 ; \mathrm{n}=13)$ wide, attached slightly posterior to middle of bothridia. Bothridia varying in shape with degree of contraction; ovoid, broadly ovoid, finely ovoid (Fig. 6B), deeply ovoid (Fig. 7B), very deeply ovoid, to finely deltoid (Fig. 7A), facially loculated, 166-240 $(205 \pm 22 ; \mathrm{n}=15)$ long by $110-235(150 \pm 32 ; \mathrm{n}=14)$ wide; bothridial margins with thin rim. Anterior region of bothridia (Fig. 6B) with 10-12 (10.6 $\pm 0.7 ; n=11)$ horizontally oriented loculi (i.e. loculi wider than long) with 10-12 complete transverse septa. Anteriormost loculus 15-25 (20 $\pm 4 ; n=13)$ long and 24-35 (31 $\pm 3 ; n=12)$ wide. Posterior region of bothridia with $4(n=11)$ nonmedial longitudinal septa dividing bothridia into 5 primary loc- uli longer than wide; outermost primary loculi on each side subdivided by $3-4(3.7 \pm 0.5 ; \mathrm{n}=9)$ diagonal septa into 4-5 small subloculi; central 2 longitudinal septa of posterior region overlapping $3-4(3.3 \pm 0.5 ; \mathrm{n}=6)$ posteriormost transverse septa of anterior region.

Loculi of distal bothridial surfaces (Fig. 7C) bearing acicular and capilliform filitriches; septa on distal bothridial surfaces (Fig. 7C) bearing acicular and capilliform filitriches and coniform spinitriches. Proximal bothridial rim (Fig. 7D) bearing capilliform filitriches greater in length than those on distal bothridial surfaces (Fig. 7C). Proximal bothridial surfaces away from rim bearing acicular filitriches throughout (Fig. 7D). Posterior margin of proximal bothridial surfaces bearing patch of coniform spinitriches (Fig. 7E) near, but not extending to, bothridial rim. Isolated cilia observed on distal and proximal bothridial surfaces. Bothridial stalks and strobila (Fig. 7F) bearing capilliform filitriches only.

Strobila with $1-4(2.3 \pm 1.0 ; \mathrm{n}=14)$ proglottids wider than long followed by $3-5(3.8 \pm 0.6 ; n=14)$ proglottids that are longer than wide. Strobila widest at terminal proglottid; terminal proglottid 490-1250 (798 \pm 209 ; $\mathrm{n}=14)$ long by $78-180(125 \pm 31 ; \mathrm{n}=14)$ wide, genital pore located $41-55 \%(49 \pm 4.7 ; n=14)$ of proglottid length from proglottid posterior margin. Immature proglottids $3-6(4.5 \pm 0.9 ; \mathrm{n}=14)$ in number. Mature proglottids $1-2$ $(1.6 \pm 0.5 ; \mathrm{n}=14)$ in number, including $0-1(0.7 \pm 0.5$; $\mathrm{n}=14$ ) vas deferens-mature proglottid.

Testes in mature proglottids $12-19(15 \pm 2.1 ; \mathrm{n}=14)$ in total number, 1 layer deep in cross section, arranged in 2 columns; columns extending from anterior margin of proglottid to anterior margin of cirrus sac, 23-42 (33 \pm 6 ; $\mathrm{n}=13)$ long by $28-50(37 \pm 8 ; \mathrm{n}=13)$ wide. Vas deferens coiled, entering anterior margin of cirrus sac, extending from level of ovarian isthmus to overlap posteriormost testes. Cirrus sac thin-walled, oval, extending medially well past midline of proglottid; cirrus sac in terminal mature proglottid 42-80 (66 $\pm 17 ; \mathrm{n}=4)$ long by 50-70 (62 \pm 9 ; $\mathrm{n}=4$ ) wide; cirrus sac in vas deferens-mature proglottids 45-90 $(71 \pm 13 ; \mathrm{n}=9)$ long by 50-100 (75 $\pm 18 ; \mathrm{n}=9)$ wide. Cirrus spinitriches present.

Vagina (Fig. 6C) thick-walled, sinuous, somewhat overlapping anterior margin of cirrus sac (Fig. 16C), extending from ootype past midline to aporal side of proglottid to anterior margin of cirrus sac, then laterally to open into genital atrium anterior to cirrus sac; vaginal sphincter absent. Seminal receptacle present. Ovary near posterior end of proglottid, H-shaped in frontal view, tetralobed in cross section, overlapping cirrus sac; ovarian lobes symmetrical; poral ovarian lobe somewhat overlapping cirrus sac; poral and aporal ovarian lobes in terminal mature proglottids $135-270(219 \pm 61 ; n=5)$ and 140-275 $(219 \pm 60 ; n=5)$ long, respectively. Poral and aporal ovarian lobes in vas deferens-mature proglottids $135-425(258 \pm 103 ; \mathrm{n}=8)$ and 155-450 (264 $\pm 108 ; \mathrm{n}=8)$ long, respectively. Maximum width of ovary $52-110(78 \pm 22 ; n=13)$. Ovarian isthmus at or anterior to midpoint of ovary; poral lobe of ovary stopping $45-150(81 \pm 21 ; \mathrm{n}=13)$ short of genital pore. Mehlis' gland posterior to ovarian isthmus, 30-45 


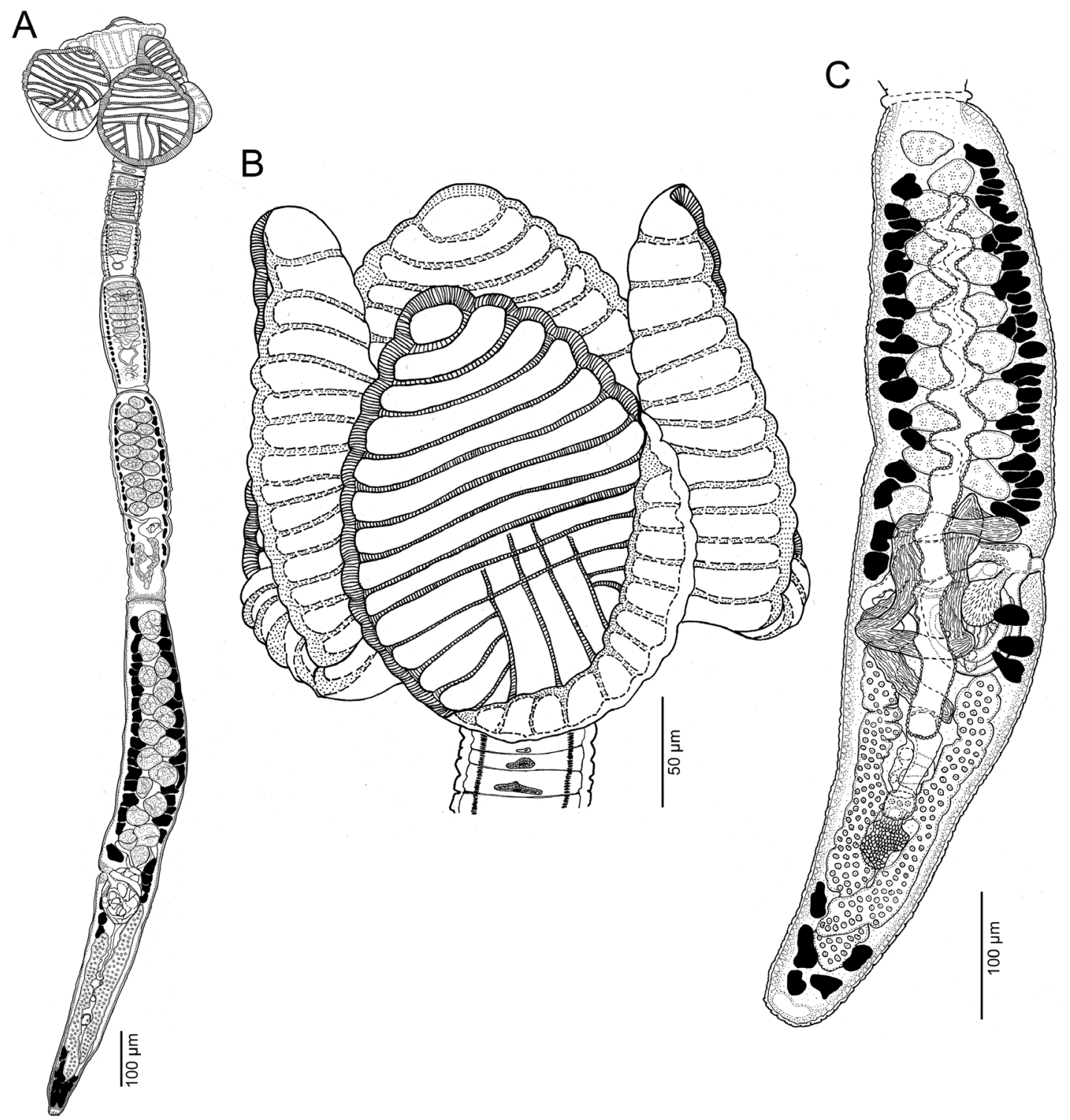

Fig. 6. Line drawings of Stillabothrium campbelli sp. n. from Himantura cf. pastinacoides. A - whole worm (holotype; MZUM [P] $2016.11[\mathrm{H}])$; B - scolex (LRP 9066); C - terminal proglottid (LRP 9067).

$(39 \pm 7 ; \mathrm{n}=7)$ long by $25-37(29 \pm 4 ; \mathrm{n}=7)$ wide. Vitellarium follicular; vitelline follicles arranged in 1 dorsal and 1 ventral column on each side of proglottid; columns extending from anterior to posterior margin of proglottid, interrupted by terminal genitalia, and mostly interrupted by ovary (Fig. 6A,C). Uterus ventral, sacciform, extending from near isthmus of ovary to near anterior margin of proglottid.

Type and only known host: Himantura cf. pastinacoides (Myliobatiformes: Dasyatidae).

Type locality: Sulu Sea off Kampung Tetabuan $\left(06^{\circ} 01^{\prime} 10^{\prime \prime N}\right.$; $\left.117^{\circ} 42^{\prime} 15^{\prime \prime E}\right)$, Sabah, Malaysian Borneo (BO98, BO-100, BO-119).

Additional localities: Sulu Sea off Sandakan $\left(05^{\circ} 50^{\prime} 20^{\prime \prime N}\right.$; $\left.118^{\circ} 07^{\prime} 16^{\prime \prime E}\right)$, Sabah, Malaysian Borneo (BO79). South China Sea off Sematan $\left(01^{\circ} 48^{\prime} 15^{\prime \prime N}\right.$; $\left.109^{\circ} 46^{\prime} 47^{\prime \prime E}\right)$, Sarawak, Malaysian Borneo (BO-168).

Site of infection: Spiral intestine.

Type material: Holotype MZUM (P) No. $2016.11(\mathrm{H})$.
Paratypes: IPCAS No. C-738; LRP Nos. 8995-8997; 90639082; 9149 (including molecular vouchers, sections and SEM specimens); MZUM (P) No. 2016.12 (P); SBC No. P-00071; USNM Nos. 1420467-1420470.

E ty m o log y: This species is named in honour of Dr. William Campbell, Nobel laureate, for his role in the development of drugs to fight parasitic infections.

Remarks. Stillabothrium campbelli sp. n. is the only Stillabothrium species treated in this study that possesses a greater number of anterior loculi than posterior loculi on the bothridia. Stillabothrium campbelli can be distinguished from both $S$. ashleyae and $S$. davidcynthiaorum in the unique configuration of the septa and loculi on its bothridia. In terms of the anterior region of the bothridia, S. campbelli possesses a total of 10-12 loculi (Fig. 6B) whereas both $S$. ashleyae and $S$. davidcynthiaorum each possess only 3 loculi (Figs. 2B, 4B). In the posterior region of the bothridia, $S$. campbelli possesses 5 loculi that are longer than wide whereas both $S$. ashleyae and $S$. da- 

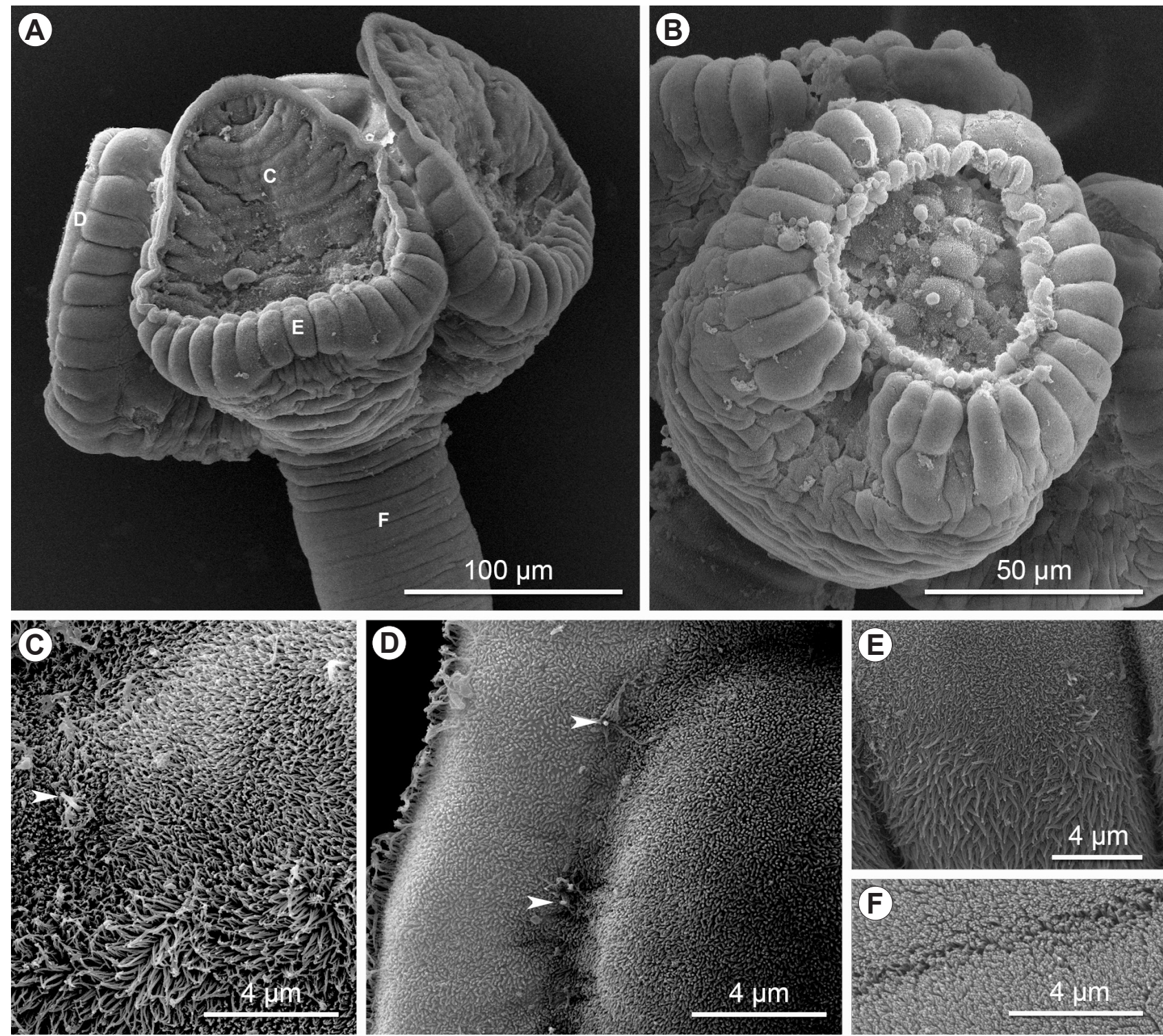

Fig. 7. Scanning electron micrographs of Stillabothrium campbelli sp. n. from Himantura cf. pastinacoides. A - scolex; letters indicate locations of other SEMs; B - bothridium; C - distal bothridial surface at third loculus (upper half) and transverse septum (lower half); $\mathbf{D}$ - proximal bothridial surface with rim; $\mathbf{E}$ - proximal bothridial surface near rim; $\mathbf{F}$ - strobila. White arrowheads indicate cilia in Fig. 7C,D.

vidcynthiaorum respectively possess 7 or 9 loculi that are longer than wide (Figs. 2B, 4B). In addition, the longitudinal septa in the posterior bothridia of $S$. campbelli extend anteriorly such that they overlap with the 3-4 posteriormost transverse septa of the anterior region of the bothridia. In $S$. ashleyae and $S$. davidcynthiaorum, the septa do not overlap.

Scolex microtriches can also be used to distinguish S. campbelli from S. ashleyae and S. davidcynthiaorum. The posterior proximal surface of bothridia in S. campbel$l i$ possess a patch of coniform spinitriches (in addition to acicular filitriches throughout) near the rim, that is restricted in distribution, whereas the proximal bothridial surface of $S$. ashleyae and $S$. davidcynthiaorum is evenly covered with coniform spinitriches and acicular filitriches. Finally, proglottid morphology can also be used to distinguish $S$. campbelli from $S$. ashleyae and $S$. davidcynthiaorum.
The cirrus sac of $S$. campbelli sp. n. is larger $(45-90 \mu \mathrm{m}$ long by $50-100 \mu \mathrm{m}$ wide) than those of $S$. ashleyae (26-42 $\mu \mathrm{m}$ long by $26-47 \mu \mathrm{m}$ wide) and of $S$. davidcynthiaorum (18-35 $\mu \mathrm{m}$ long by $24-38 \mu \mathrm{m}$ wide), and it extends further across the midline (Figs. 6C, 16C), than in the latter two species (Figs. 2C, 4C, 16A,B).

Stillabothrium campbelli is reported from $H$. cf. pastinacoides from three different localities in Malaysian Borneo. It should be noted that the stingray host specimens of S. campbelli in this study, BO-61, BO-79, BO-98, BO-100, BO-119 and BO-168, are identified as $H$. cf. pastinacoides (Caira et al. 2012), but that identification awaits expert verification. Given that Naylor et al. (2012b) showed that two species of stingray similar to $H$. pastinacoides (i.e. $H$. cf. pastinacoides 1 and $H$. cf. pastinacoides 2) co-occur in the region sampled, it is possible that $S$. campbel$l i$ sp. n. parasitises either or both. Additional specimens 


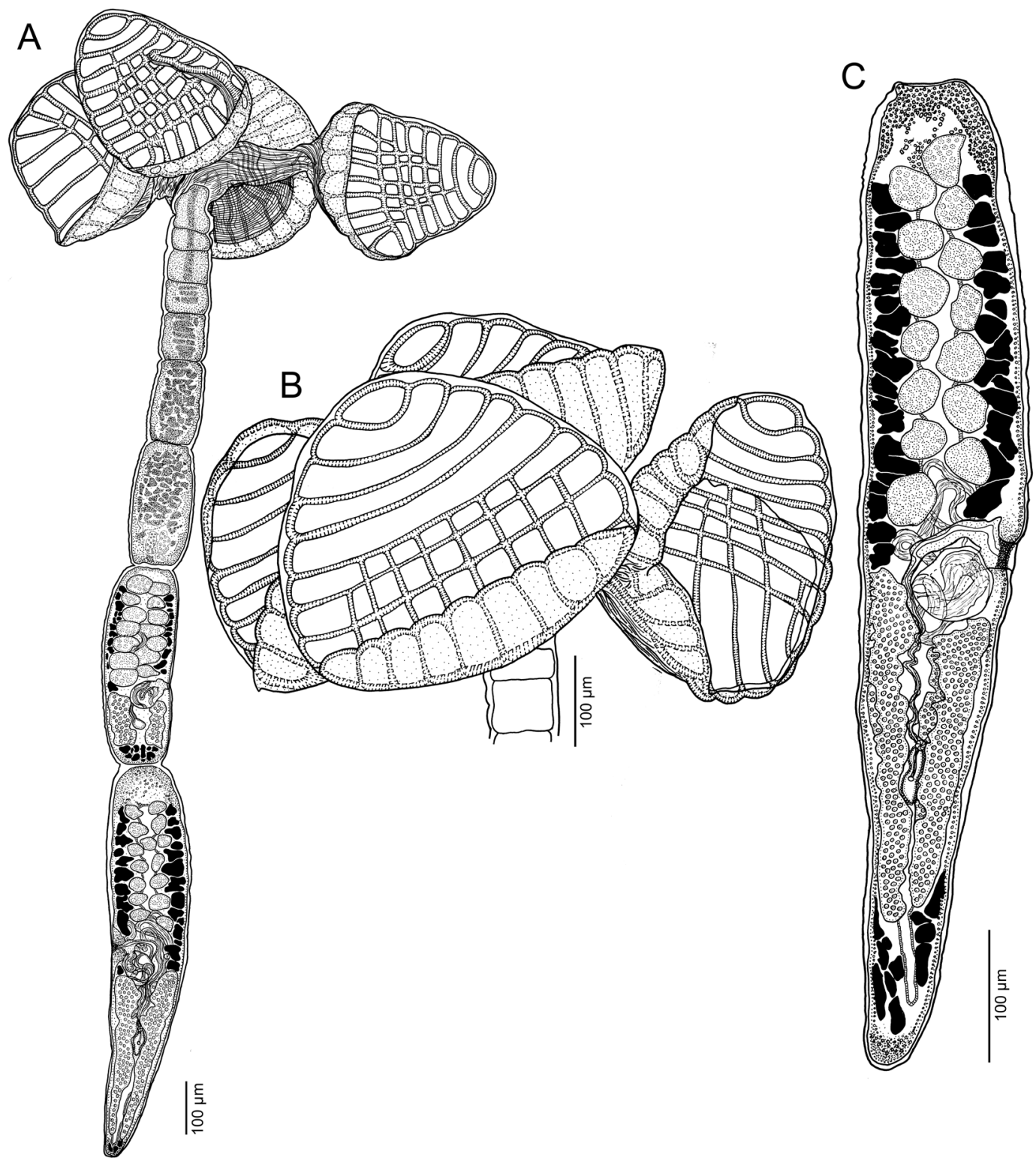

Fig. 8. Line drawings of Stillabothrium hyphantoseptum sp. n. from Pastinachus solocirostris Last, Manjaji et Yearsley. A - whole worm (holotype; MZUM [P] 2016.13 [H]); B - scolex (LRP 9092); C - terminal proglottid (LRP 9088).

morphologically similar to $S$. campbelli were encountered in H. uarnacoides (BO-118). Further studies are needed to determine whether Stillabothrium specimens from $H$. uarnacoides are conspecific with $S$. campbelli or represent an undescribed species of Stillabothrium.

Four specimens of $S$. campbelli were included in the phylogenetic analysis (Fig. 1, Table 1).

\section{Stillabothrium hyphantoseptum Herzog, Bergman et} Reyda sp. n.

Figs. 1, 8, 9, 16D

\section{ZooBank number for species:}

urn:lsid:zoobank.org:act:97362AA0-762D-4C87-B5ED-0A3664D69E98

Description (based on whole mounts of 29 complete mature worms, cross sections of 2 strobila and longitudinal sections of 2 scoleces and 2 scoleces prepared for SEM): Worms (Fig. 8A) euapolytic, acraspedote, 1.10-2.28 mm
$(1.64 \pm 0.3 ; n=29)$ long, greatest width 368-933(601 \pm 140 ; $\mathrm{n}=29)$ at level of scolex; $5-9(7.3 \pm 1.1 ; \mathrm{n}=29)$ proglottids per worm. Cephalic peduncle lacking; small darkly staining germinative zone present.

Scolex (Fig. 8B) consisting of scolex proper bearing 4 stalked bothridia. Stalks 49-270 (119 $\pm 54 ; \mathrm{n}=22)$ long by 48-101 $(73 \pm 15 ; \mathrm{n}=27)$ wide, attached slightly posterior to middle of bothridia. Bothridia varying in shape with degree of contraction, from finely ovoid (Fig. 8A), broadly ovoid (Fig. 8B), to broadly deltoid (Fig. 9A), facially loculated, 247-390 (319 $\pm 35 ; \mathrm{n}=24)$ long by $213-360$ $(288 \pm 37 ; \mathrm{n}=24)$ wide; bothridial margins with thin rim. Anterior region of bothridia (Figs. 8A,B, 9B) with 6-8 horizontally oriented loculi (i.e. loculi wider than long) with 6-8 complete transverse septa $(7.2 \pm 0.5 ; \mathrm{n}=26)$. Anteriormost loculus $30-51(40 \pm 6 ; \mathrm{n}=27)$ long by $54-90$ $(71 \pm 10 ; \mathrm{n}=29)$ wide. Posterior region of bothridia with $8(n=21)$ nonmedial longitudinal septa dividing bothrid- 

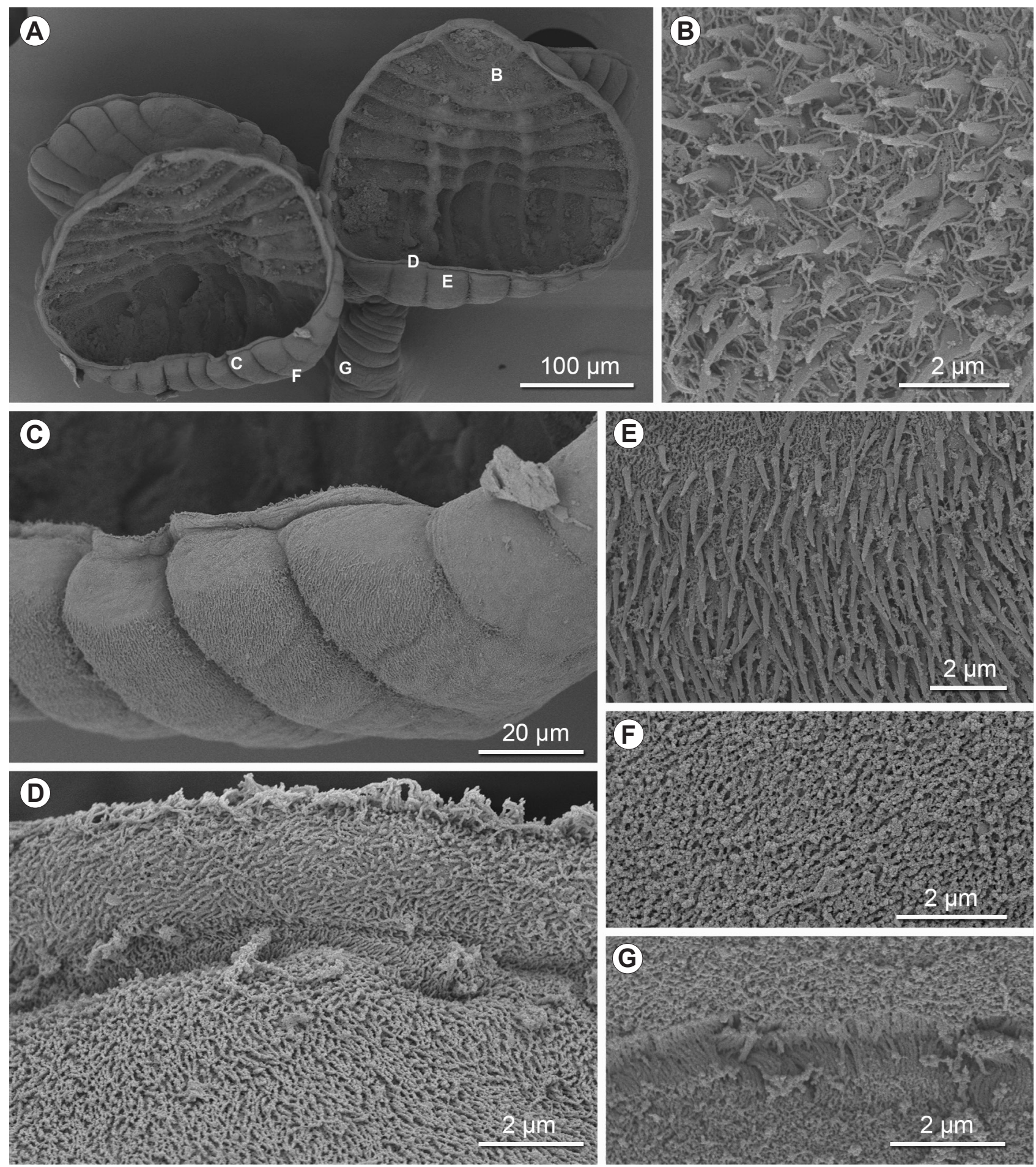

Fig. 9. Scanning electron micrographs of Stillabothrium hyphantoseptum sp. n. from Pastinachus solocirostris Last, Manjaji et Yearsley. A - scolex; letters indicate locations of other SEMs; B - distal bothridial surface at second loculus and transverse septum; C, D - proximal bothridial surface with rim; $\mathbf{E}$ - proximal bothridial surface near rim; $\mathbf{F}$ - proximal bothridial surface; $\mathbf{G}$ - strobila.

ia into 9 loculi longer than wide; majority of longitudinal septa overlapping posteriormost $3-6(4.3 \pm 0.9 ; n=13)$ transverse septa of anterior region of bothridia, resulting in a grid-like pattern of septa and loculi in the centre of bothridium (Fig. 8A,B).

Loculi and septa of distal bothridial surfaces (Fig. 9B) bearing capilliform filitriches and coniform spinitriches. Proximal bothridial rim (Fig. 9C,D) bearing capilliform filitriches (Fig. 9B). Proximal bothridial surfaces away from rim bearing acicular filitriches throughout bothridium (Fig. 9D,E,F). Posterior margin of proximal bothridial surfaces bearing a patch of coniform spinitriches (Fig. 9C,E) near, but not extending to, bothridial rim. Bothridial stalks and strobila (Fig. 9G) bearing capilliform filitriches only.

Strobila with $2-5(3.5 \pm 0.9 ; \mathrm{n}=29)$ proglottids wider than long followed by $2-6(3.9 \pm 0.8 ; n=29)$ proglottids longer than wide. Strobila widest at terminal proglottid; terminal proglottid 381-840 $(601 \pm 127 ; \mathrm{n}=29)$ long 
by $78-155(12 \pm 18 ; \mathrm{n}=29)$ wide; genital pore located $50-61 \%(55 \pm 3.6 ; n=29)$ of proglottid length from proglottid posterior margin. Immature proglottids 4-8 $(6.0 \pm 1.1 ; \mathrm{n}=29)$ in number. Mature proglottids $1-2$ $(1.3 \pm 0.5 ; \mathrm{n}=29)$ in number, including $0-1(0.6 \pm 0.5$; $\mathrm{n}=29)$ vas deferens-mature proglottid.

Testes in mature proglottids $9-16(13 \pm 1.9 ; \mathrm{n}=28)$ in total number, 1 layer deep in section, arranged in 2 columns; columns extending from anterior margin of proglottid to anterior margin of cirrus sac, $23-57(33 \pm 7 ; \mathrm{n}=25)$ long by 27-49 (39 $\pm 7 ; \mathrm{n}=25)$ wide. Vas deferens coiled, entering anterior margin of cirrus sac, extending from level of ovarian isthmus to overlap posteriormost testes. Cirrus sac thin-walled, oval, extending medially past midline of proglottid; cirrus sac in terminal mature proglottid 45-69 $(57 \pm 6 ; \mathrm{n}=12)$ long by $38-60(49 \pm 7 ; \mathrm{n}=12)$ wide; cirrus sac in vas deferens-mature proglottids 52-79 (63 \pm 8 ; $\mathrm{n}=16)$ long by $45-63(54 \pm 5 ; \mathrm{n}=16)$ wide. Cirrus spinitriches present.

Vagina (Figs. 8C, 16D) thick-walled, weakly sinuous, somewhat overlapping medial portion of cirrus sac (Fig. 8A), extending along midline of proglottid from ootype region to anterior margin of cirrus sac, then laterally to open into genital atrium anterior to cirrus sac; vaginal sphincter absent. Seminal receptacle present. Ovary near posterior end of proglottid, H-shaped in frontal view, tetralobed in cross section. Ovarian lobes asymmetrical; poral ovarian lobe somewhat overlapping cirrus sac; poral and aporal ovarian lobes in terminal mature proglottids $125-201(155 \pm 28 ; \mathrm{n}=9)$ and 140-213 $(165 \pm 27 ; \mathrm{n}=9)$ long, respectively. Poral and aporal ovarian lobes in vas deferens-mature proglottids $175-290(216 \pm 27 ; \mathrm{n}=15)$ and 175-290 (228 $\pm 34 ; \mathrm{n}=15)$ long, respectively. Maximum width of ovary $68-114(92 \pm 12 ; n=24)$. Ovarian isthmus at or anterior to midpoint of ovary; poral lobe of ovary stopping 30-80 (53 $\pm 14 ; \mathrm{n}=24)$ short of genital pore. Mehlis' gland posterior to ovarian isthmus, 24-70 $(40 \pm 11 ; \mathrm{n}=20)$ long by $14-30(21 \pm 5 ; \mathrm{n}=18)$ wide. Vitellarium follicular, 1 dorsal and 1 ventral column on each side of proglottid; columns extending from anterior to posterior margin of proglottid, interrupted by terminal genitalia, and interrupted by ovary (Fig. 8A,C). Uterus ventral, sacciform, extending from posterior margin of proglottid to near anterior margin of proglottid.

Type and only known host: Pastinachus solocirostris Last, Manjaji et Yearsley, Roughnose stingray (Myliobatiformes: Dasyatidae).

Type locality: South China Sea off Mukah (02 $533^{\prime} 52^{\prime \prime N}$; $112^{\circ} 05^{\prime} 44^{\prime \prime E}$ ), Sarawak, Malaysian Borneo (BO-267).

Additional localities: Java Sea off Singkawang (Pasar Bringin) $\left(00^{\circ} 55^{\prime} 06^{\prime \prime} \mathrm{N}\right.$; $\left.108^{\circ} 58^{\prime} 58^{\prime \prime} \mathrm{E}\right)$, West Kalimantan, Indonesian Borneo (KA-148).

Site of infection: Spiral intestine.

Type material: Holotype MZUM (P) No. $2016.13(\mathrm{H})$. Paratypes: IPCAS No. C-741; LRP Nos. 9003-9004; $9083-$ 9117 (including molecular vouchers, sec-tions, and SEM specimens); MZUM (P) No. 2016.14 (P)-2016.15 (P); SBC No. P-00072; USNM Nos. 1420471-1420477.

E t y m o log y: This species is named for the grid-like pattern of septa in the centre of the bothridium. The name is a combination of the Latin 'hyphantos', meaning woven, and the Latin 'septum'.

Remarks. The most striking characteristic of $S$. hyphantoseptum sp. $\mathrm{n}$. is the extensive grid-like appearance of the septa on the centre of the bothridia (Fig. 8A,B). This configuration results from the extensive overlap of transverse (anterior) septa and longitudinal (posterior) septa. This feature readily distinguishes $S$. hyphantoseptum from $S$. ashleyae and $S$. davidcynthiaorum, both of which lack overlapping septa. The only other described species of Stillabothrium with overlapping transverse and longitudinal septa is $S$. campbelli (Fig. 6A,B). Although the centre of bothridia of $S$. campbelli is grid-like, the grid-like area is less extensive than in $S$. hyphantoseptum (compare Figs. 6B and 8B). In S. campbelli, the posteriormost 3-4 transverse septa are overlapped by its central 2 longitudinal septa, whereas in $S$. hyphantoseptum the posteriormost 3-6 transverse septa are overlapped by most of its eight longitudinal septa. The number of loculi that are wider than long in the anterior region of bothridia is also different between the two species (6-8 in S. hyphantoseptum vs 10-12 in $S$. campbelli).

In terms of proglottid morphology, S. hyphantoseptum sp. n. can be distinguished from $S$. ashleyae, $S$. davidcynthiaorum and $S$. campbelli in its possession of a uterus that extends to the posterior margin of the proglottid (Fig. 8C), whereas in the latter three species the uterus only extends posteriorly to the ovarian isthmus (Figs. 4C, 6C; not illustrated for $S$. ashleyae, but observed).

Stillabothrium hyphantoseptum is the only species of Stillabothrium reported from a species of Pastinachus Rüppell. The host species, P. solocirostris (roughnose stingray) was described by Last et al. (2005) as part of the same survey work that made the current study possible.

Two specimens of $S$. hyphantoseptum were included in the phylogenetic analysis (Fig. 1, Table 1).

Stillabothrium jeanfortiae Forti, Aprill et Reyda sp. n.

Figs. 1, 10, 11, 16E

ZooBank number for species:

urn:1sid:zoobank.org:act:D2B25027-058D-4E3D-B880-F1FA5AB763DB

Description (based on whole mounts of 20 complete mature worms, cross sections of 1 strobila and longitudinal sections of 1 scolex and 2 scoleces prepared for SEM): Worms (Fig. 10A) euapolytic, acraspedote, 1.7-3.9 mm $(2.5 \pm 0.6 ; \mathrm{n}=20)$ long, greatest width 428-822 (588 \pm 121 ; $\mathrm{n}=20)$ at level of scolex; $5-10(7.1 \pm 1.2 ; \mathrm{n}=20)$ proglottids per worm. Cephalic peduncle lacking, small darkly staining germinative zone present.

Scolex (Fig. 10B) consisting of scolex proper bearing four stalked bothridia. Stalks 30-125 $(77 \pm 25 ; \mathrm{n}=16)$ long by $65-140(94 \pm 18 ; n=16)$ wide, attached slightly posterior to middle of bothridia. Bothridia (Figs. 10A,B, 11A) always constricted but varying in shape with degree of contraction, broadly (Fig. 10B), shallowly (Fig. 10A), very shallowly (Fig. 11A), or depressed deltoid, facially loculat- 


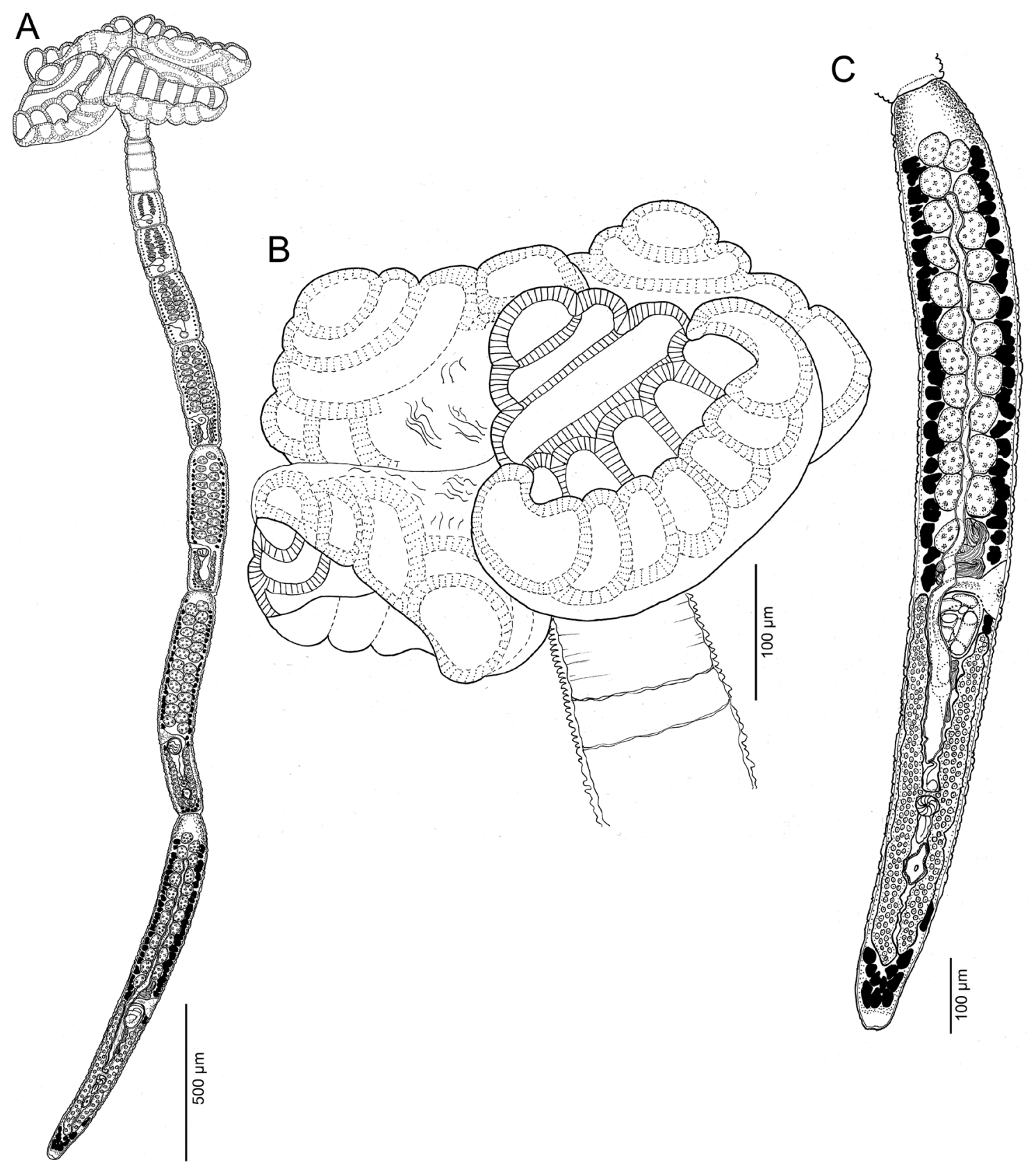

Fig. 10. Line drawings of Stillabothrium jeanfortiae sp. n. from Himantura australis Last, White et Naylor. A - whole worm (holotype; QM G235198); B - scolex (LRP 9123); C - terminal proglottid (holotype; QM 235198).

ed, 218-305 (259 $\pm 21 ; \mathrm{n}=20)$ long by 255-460 $(339 \pm 58$; $\mathrm{n}=20$ ) wide. Anterior region of bothridia (Figs. 10A,B, 11A) with 3 horizontally oriented loculi (i.e. loculi wider than long) with 3 complete complete transverse septa $(\mathrm{n}=20)$. Anteriormost loculus $35-60(46 \pm 7 ; \mathrm{n}=18)$ long by $64-115(81 \pm 16 ; n=18)$ wide. Posterior region of bothridia (Figs. 10A, B, 11A) with $6(\mathrm{n}=20)$ nonmedial longitudinal septa dividing bothridia into 7 loculi longer than wide; longitudinal septa not overlapping transverse septa in anterior region of bothridia.

Loculi and septa of distal bothridial surfaces (Fig. 11B) bearing coniform spinitriches and, less conspicuously, capilliform filitriches. Proximal bothridial rim (Fig. 11C) bearing capilliform filitriches greater in length than those on distal bothridial surfaces (Fig. 11B). Proximal bothridial surfaces away from rim bearing densely arranged capilliform filitriches throughout bothridium (Fig. 11E). Proximal bothridial surfaces near bothridial rim bearing coniform spinitriches (Fig. 11D) that do not extend to stalks. Bothridial stalks and strobila (Fig. 11F) bearing capilliform filitriches only.

Strobila with $2-5(3.2 \pm 0.8 ; n=20)$ proglottids wider than long followed by $3-7(3.9 \pm 1.0 ; n=20)$ proglottids longer than wide. Strobila widest at terminal proglottid; terminal proglottid 724-1260 (1013 $\pm 185 ; \mathrm{n}=20)$ long by $92-192(132 \pm 24 ; n=20)$ wide; genital pore located $42-56 \%(48 \pm 4 ; \mathrm{n}=20)$ of proglottid length from proglottid posterior margin. Immature proglottids 4-8 (5.8 \pm 1.0 ; $\mathrm{n}=20)$ in number. Mature proglottids $1-2(1.4 \pm 0.5$; $\mathrm{n}=20)$ in number, including $0-1(0.3 \pm 0.5 ; \mathrm{n}=20)$ vas deferens-mature proglottid. 

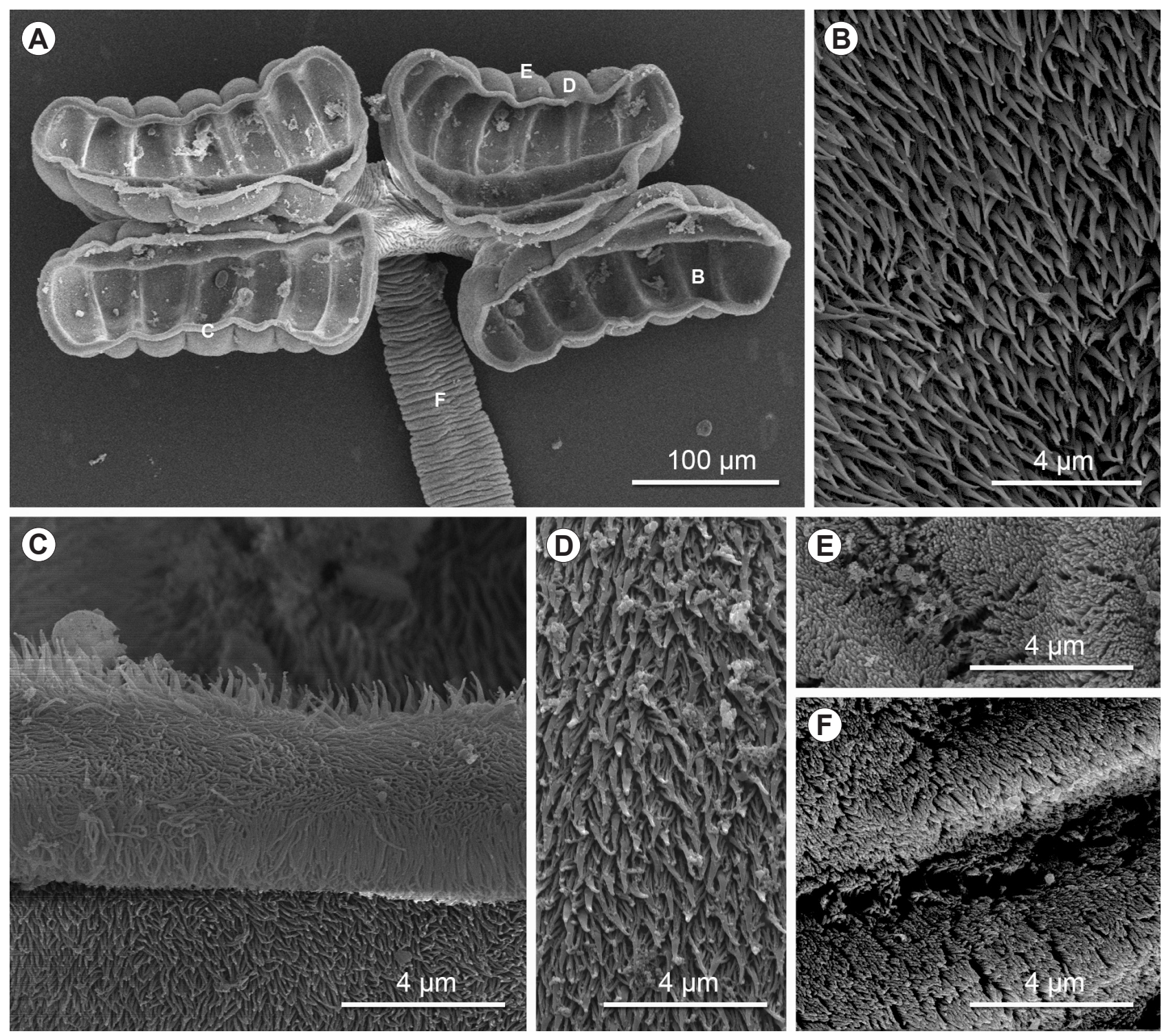

Fig. 11. Scanning electron micrographs of Stillabothrium jeanfortiae sp. n. from Himantura australis Last, White et Naylor. A - scolex; letters indicate locations of other SEMs; $\mathbf{B}$ - distal bothridial surface in posterior borthridium; $\mathbf{C}$ - proximal bothridial surface with rim; $\mathbf{D}$ - proximal bothridial surface near rim; $\mathbf{E}$ - proximal bothridial surface; $\mathbf{F}$ - strobila.

Testes in mature proglottids $20-29(23 \pm 2 ; \mathrm{n}=20)$ in total number, in 1 layer deep in section, arranged in 2 columns (Fig. 10C), columns extending from anterior margin of proglottid to anterior margin of cirrus sac, 26-52 $(38 \pm 8 ; \mathrm{n}=16)$ long by $29-55(42 \pm 7 ; \mathrm{n}=16)$ wide. Vas deferens coiled, entering anterior margin of cirrus sac, extending from level of ovarian isthmus anteriorly to overlap posteriormost testes. Cirrus sac thin-walled, oval, extending medially past midline of proglottid. Cirrus sac in terminal mature proglottid $55-81(72 \pm 8 ; \mathrm{n}=15)$ long by $47-73$ $(59 \pm 8 ; \mathrm{n}=15)$ wide; cirrus sac in vas deferens-mature proglottids $80-87(84 \pm 3 ; n=5)$ long by $62-80(72 \pm 7$; $\mathrm{n}=5$ ) wide. Cirrus spinitriches present.

Vagina (Fig. 10C) thick-walled, non-sinuous, somewhat overlapping medial portion of cirrus sac (Fig. 10C), extending along midline of proglottid from ootype region to anterior margin of cirrus sac, then laterally to open into genital atrium anterior to cirrus sac; vaginal sphincter absent. Seminal receptacle present. Ovary near posterior end of proglottid, $\mathrm{H}$-shaped in frontal view, tetralobed in cross section; ovarian lobes somewhat asymmetrical; poral and aporal ovarian lobes in terminal mature proglottids $238-396(304 \pm 47 ; \mathrm{n}=12)$ and $265-394(318 \pm 45 ; \mathrm{n}=12)$ long, respectively. Poral and aporal ovarian lobes in vas deferens-mature proglottids $355-486(412 \pm 58 ; \mathrm{n}=6)$ and 370-488 (434 $\pm 48 ; \mathrm{n}=6)$ long, respectively. Maximum width of ovary $60-122(91 \pm 19 ; \mathrm{n}=17)$. Ovarian isthmus at or posterior to midpoint of ovary; poral lobe of ovary stopping 18-70 $(51 \pm 14 ; \mathrm{n}=17)$ short of genital pore. Mehlis' gland well posterior to ovarian isthmus, 32-72 $(47 \pm 13 ; \mathrm{n}=16)$ long by $22-35(28 \pm 4 ; \mathrm{n}=16)$ wide. Vitellarium follicular; vitelline follicles arranged in 1 dorsal and 1 ventral column on each side of proglottid; columns extending from anterior to posterior margin of proglottid, interrupted by terminal genitalia and mostly interrupted by ovary (Fig. 10A,C). Uterus ventral, sacciform extending 
from near ovarian isthmus to near anterior margin of proglottid.

Type and only known host: Himantura australis Last, White et Naylor, Reticulate whipray (Dasyatidae: Myliobatiformes).

Type and only known locality: Gulf of Carpentaria (Indian Ocean) off Weipa (12³5'11"S; 141 $\left.{ }^{\circ} 42^{\prime} 34^{\prime \prime E}\right)$, Queensland, Australia (CM03-3, CM03-25, CM03-65).

Site of infection: Spiral intestine.

Type material: Holotype QM No. G235198. Paratypes: LRP Nos. 8999; 9118-9133 (including molecular vouchers, sections, and SEM specimens); QM Nos. G235199-G235200; USNM Nos. 1420478-1420483; IPCAS No. C-740.

E t y m o log y: This species is named in loving memory of Jean Forti, mother of K.S. Forti, for her support of her daughter's education.

Remarks. Stillabothrium jeanfortiae sp. n. is the fifth new Stillabothrium species described in this study. Its configuration of bothridial septa is unique relative to its four described congeners. Stillabothrium jeanfortiae is distinguished from $S$. ashleyae and $S$. davicynthiae in that it lacks, rather than possesses, marginal septa in the posterior region of bothridia. It also differs from $S$. ashleyae and $S$. davicynthiae in that the three loculi in its anterior region of bothridia are oriented in tandem, instead of occurring as a row of one and then two loculi. Stillabothrium jeanfortiae can be distinguished from $S$. campbelli and S. hyphantoseptum in that it lacks, rather than posseses, septa that overlap one another.

Stillabothrium jeanfortiae is described from the stingray Himantura australis from the Gulf of Carpentaria in northern Australia. Specimens similar in morphology to $S$. jeanfortiae were encountered in H. leoparda (NT-117), also from the Gulf of Carpentaria, but confirmation of the identity of this material awaits further study. Specimens with a similar bothridial morphology to that of S. jeanfortiae were also encountered in a diversity of species of Himantura during survey work in Borneo. Those specimens can be readily distinguished from $S$. jeanfortiae based on proglottid morphology, but their taxonomic treatment also awaits further study.

One specimen of $S$. jeanfortiae was included in the phylogenetic analysis (Fig. 1, Table 1). It grouped with two undescribed species of Stillabothrium from Senegal.

Stillabothrium cadenati (Euzet, 1954) Healy et Reyda, 2016 comb. $n$. Figs. 1, 12-14, 16E

Sy no n y m: Rhinebothrium cadenati Euzet, 1954

Informal synonyms: Rhinebothriinae New genus $3 \mathrm{ca}$ denati of Healy et al. (2009), Caira et al. (2014), Ruhnke et al. (2015), Marques and Caira (2016).

ZooBank number for species:

urn:lsid:zoobank.org:act:9274C612-40F1-4F66-839C-DE145BC0C01C

Redescription (based on specimens collected from Z. schoenleinii consisting of whole mounts of 6 complete mature worms, 5 strobilae and 2 scoleces; cross sections of
1 strobila and longitudinal sections of 2 scoleces [including 1 in situ scolex], and 1 specimen prepared for SEM): Worms euapolytic, slightly craspedote (Fig. 12A), 1.04-1.77 mm $(1.35 \pm 0.3 ; \mathrm{n}=6)$ long, greatest width 439-694 (568 \pm 96 ; $\mathrm{n}=7)$ at level of scolex; 5-7 (5.7 $\pm 0.8 ; \mathrm{n}=6)$ proglottids per worm. Cephalic peduncle lacking; small darkly staining germinative zone present. Scolex (Figs. 12A, 14A) consisting of scolex proper bearing four stalked bothridia. Stalks 39-128 (86 $\pm 33 ; \mathrm{n}=8)$ long by 40-77 (60 \pm 13 ; $\mathrm{n}=8$ ) wide, attached slightly posterior to middle of bothridia. Bothridia (Figs. 12A,B, 14A,B) varying in shape with degree of contraction, deeply (Fig. 12A), finely deltoid or broadly deltoid (Figs. 12B, 14A,B), facially loculated, $285-378(328 \pm 38 ; \mathrm{n}=6)$ long by 201-355 (274 \pm $64 ; \mathrm{n}=7$ ) wide. Anterior region of bothridia (Figs. 12A,B) with 3 horizontally oriented loculi (i.e. loculi wider than long) with 3-4 $(3.8 \pm 0.4 ; \mathrm{n}=6)$ complete transverse septa; fourth complete but reduced transverse septum (Fig. 12B) observed in 5 of 6 specimens. Anteriormost loculus 58-105 $(77 \pm 14 ; \mathrm{n}=8)$ long and 74-118 $(108 \pm 14 ; \mathrm{n}=8)$ wide. Posterior region of bothridia (Fig. 12A,B) with $4(\mathrm{n}=8)$ nonmedial longitudinal septa dividing bothridia into 5 loculi longer than wide; longitudinal septa in posterior region of bothridia overlapping posteriormost (fourth) transverse septum in anterior region of bothridia (Fig. 12B). Muscle fibres other than septa but parallel to bothridial surface also observed on bothridia (Fig. 12A). All septa appear as ridges in section with proximal and distal portions different (Fig. 13); proximal portion of septa formed by underlying bothridial wall, consisting of radial muscles oriented with proximal ends of fibres adjacent to each other; distal portion of septa formed by separate muscle bundle; proximal and distal portions of septa separated by a triangular gap.

Loculi (Fig. 14D) and septa (Fig. 14E) of distal bothridial surfaces bearing coniform spinitriches and capilliform filitriches; spinitriches lacking on distal bothridial margin and rim (Fig. 14C). Proximal bothridial rim (Fig. 14C) bearing capilliform filitriches greater in length than those on distal bothridial surfaces (Fig. 14D,E). Proximal bothridial surfaces away from rim and stalks bearing coniform spinitriches and capilliform filitriches (Fig. 14F,G). Strobila bearing capilliform filitriches only.

Strobila with 3-4 (3.2 $\pm 0.4 ; \mathrm{n}=6)$ proglottids wider than long followed by $2-4(2.5 \pm 0.8 ; \mathrm{n}=6)$ proglottids longer than wide. Strobila widest at terminal proglottid; terminal proglottid 467-1005 $(\mathrm{n}=11)$ long by 103-139 $(n=11)$ wide; genital pore located $64-73 \%(n=11)$ of proglottid length from proglottid posterior margin. Genital atrium expansive, $38-68(51 \pm 10 ; \mathrm{n}=11)$ long by $31-49$ $(40 \pm 7 ; n=11)$ wide, with convoluted, muscular walls. Immature proglottids $4-5(4.5 \pm 0.5 ; \mathrm{n}=6)$ in number. Mature proglottids $1-2(1.4 \pm 0.5 ; \mathrm{n}=11)$ in number, including $0-1$ $(0.7 \pm 0.5 ; \mathrm{n}=11)$ vas deferens-mature proglottids.

Testes in mature proglottids $7-13(10.8 \pm 2 ; n=12)$ in total number, 1 layer deep in section, arranged in 1-3 ( $2 \pm 0.4 ; \mathrm{n}=11$ ) though usually 2 , columns (Fig. 12C); columns extending from near anterior margin of proglottid to anterior margin of vagina, $22-36(30 \pm 4 ; n=11)$ long by $29-50(38 \pm 6 ; n=11)$ wide. Vas deferens coiled, entering 


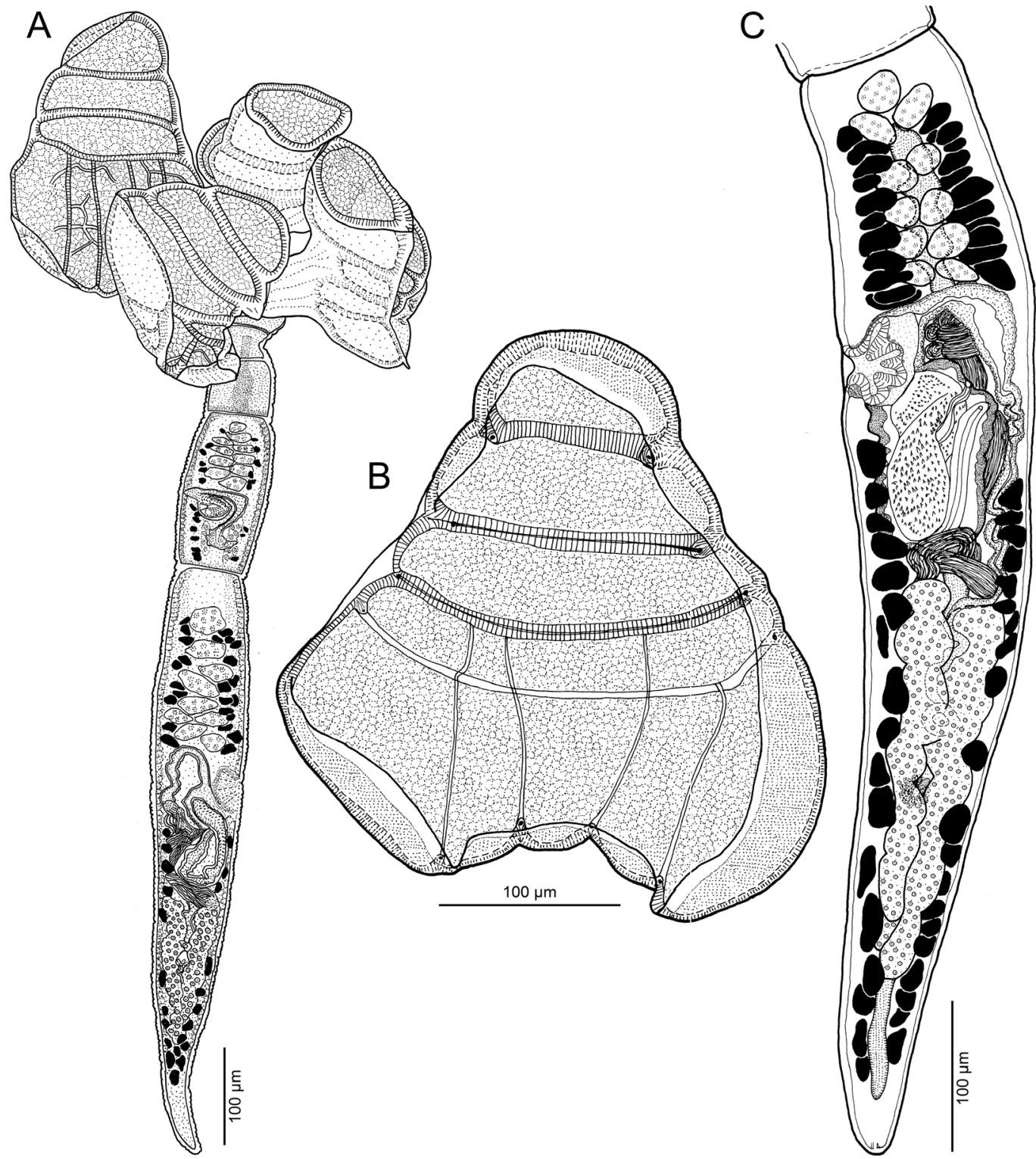

Fig. 12. Line drawings of Stillabothrium cadenati comb. n. from Zanobatus schoenleinii (Müller et Henle). A - whole worm (LRP 9135); B - bothridium (LRP 9134); C - terminal proglottid (LRP 9136).

anterior margin of cirrus sac, extending anterior to ovarian isthmus to near anterior vagina. Cirrus sac thick-walled and relatively large, oval and bent posteriorly, extending medially past midline of proglottid; cirrus sac in terminal mature proglottid $85-152(119 \pm 47 ; \mathrm{n}=2)$ long by $58-62$ $(60 \pm 3 ; \mathrm{n}=2)$ wide; cirrus sac in vas deferens-mature proglottids $103-171(136 \pm 23 ; \mathrm{n}=8)$ long by $50-75(67 \pm 8$; $\mathrm{n}=8)$ wide. Cirrus spinitriches present, 3.5-6.1 (4.3 \pm 0.9 ; $\mathrm{n}=10)$ long by $2.0-3.7(2.8 \pm 0.5 ; \mathrm{n}=10)$ wide at base.

Vagina (Fig. 12A,C) thick-walled, sinuous, not overlapping cirrus sac, recurved (Figs. 12C, 16F); poral portion expanded; medial and posterior portion abruptly narrowed; extending from ootype past midline to aporal side of proglottid to anterior margin of cirrus sac, then laterally to open into genital atrium anterior to cirrus sac; vaginal sphincter absent. Seminal receptacle present. Ovary near posterior end of proglottid, lobulated, $\mathrm{H}$-shaped in frontal view, tetralobed in cross section, not overlapping cirrus sac; ovarian lobes asymmetrical; poral and aporal ovarian lobes in terminal mature proglottids 125-215 $(170 \pm 64 ; \mathrm{n}=2)$ and $125-225(175 \pm 71 ; \mathrm{n}=2)$ long, respectively. Poral and aporal ovarian lobes in vas deferens-mature proglottids 120-350 (222 $\pm 71 ; \mathrm{n}=9)$ and 125-350 (218 $\pm 69 ; \mathrm{n}=9)$ long, respectively. Maximum width of ovary $48-87(62 \pm 13 ; n=10)$. Ovarian isthmus at or anterior to midpoint of ovary; poral lobe of ovary stopping 90-190 $(145 \pm 35 ; \mathrm{n}=10)$ short of genital pore. Mehlis' gland posterior to ovarian isthmus, 25-40 $(33 \pm 5 ; \mathrm{n}=10)$ long by $16-25(20 \pm 3 ; \mathrm{n}=10)$ wide. Vitellarium follicular; vitelline follicles arranged in 1 dorsal and 1 ventral column on each side of proglottid; columns extending from anterior to posterior margin of proglottid, interrupted by terminal genitalia, not interrupted by ovary (Fig. 12A,C). Uterus ventral, sacciform, extending from posterior margin of proglottid to near anterior margin of proglottid. 


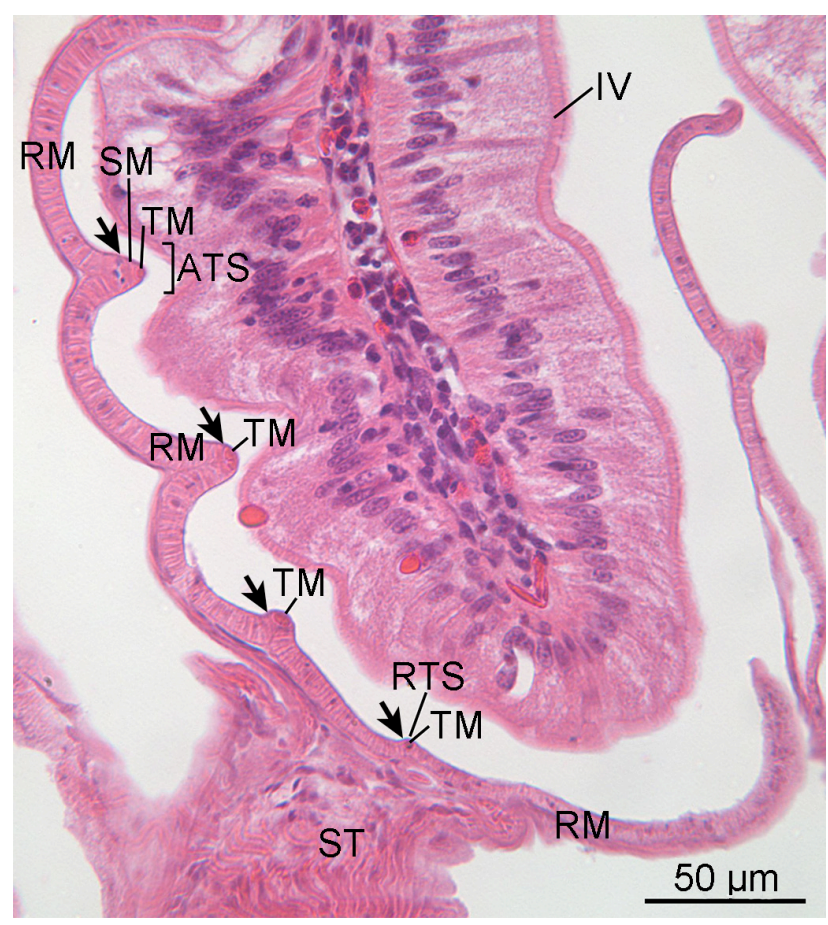

Fig. 13. Histological sections through bothridium of Stillabothrium cadenati (Euzet, 1954) comb. n. from Zanobatus schoenleinii (Müller et Henle). Arrows indicate divisions between proximal and distal portions of transverse septa. Abbreviations: ATS - anteriormost transverse septum; IV - intestinal villus; RM - radial musculature; RTS - reduced transverse septum; SM - septal musculature; ST - stalk; TM - transverse muscle bundle.

Type host: Zanobatus schoenleini [sic!] (=schoenleinii)(Müller et Henle), striped panray (Rhinopristiformes: Zanobatidae).

Additional host: Rhinobatos rhinobatos (Linnaeus), Common guitarfish (Rhinopristiformes: Rhinobatidae).

Type locality: Gorée Island, Senegal.

Additional localities: Atlantic Ocean off Ouakam $\left(14^{\circ} 42^{\prime} 54^{\prime \prime N} ; 1^{\circ} 29^{\prime} 28^{\prime \prime} \mathrm{W}\right)$ (SE-28) and Soumbédioune $\left(14^{\circ} 40^{\prime} 42^{\prime \prime N}\right.$; $\left.17^{\circ} 27^{\prime} 42^{\prime \prime} \mathrm{W}\right)$ (SE-201) in Dakar, and Joal $\left(14^{\circ} 10^{\prime} 30^{\prime \prime N}\right.$; $\left.16^{\circ} 51^{\prime} 12^{\prime \prime} \mathrm{W}\right)$ (SE-299) and Kafountine $\left(12^{\circ} 55^{\prime} 41^{\prime \prime N} ; 16^{\circ} 45^{\prime} 10^{\prime \prime} \mathrm{W}\right)$ (SE-289), Senegal.

Site of infection: Spiral intestine.

Type material: Unknown.

Material examined (vouchers): LRP Nos. 90009002; 9134-9148 (including molecular vouchers, sections and SEM specimens); MNHN Nos. HEL580-HEL581; USNM No. 1420484

Remarks. Type specimens of $S$. cadenati comb. n. were not available for this study. In the original description of $S$. cadenati, Euzet (1954) did not provide specimen deposition information. It is possible that the specimens were in the personal collection of the late Louis Euzet, a collection now transferred to the Museum National d'Histoire Naturelle (MNHN) in Paris, France. Examination of that collection by the curator, however, did not reveal the presence of any specimens of $S$. cadenati. The material on which this redescription was based were newly collected, topotypic specimens of $S$. cadenati The specimens were collected from the type host at Ouakam and Soumbédioune on the west coast of Dakar, Senegal, approximately 12 and seven $\mathrm{km}$, respectively away from Gorée island, the type locality of this species. Gorée lies $2.5 \mathrm{~km}$ off the eastern coast of Dakar. Specimens of $S$. cadenati were also obtained from the type host in Joal, Senegal.

Two specimens of $S$. cadenati were included in the phylogenetic analysis (Fig. 1, Table 1). One was from the type host, $Z$. schoenleinii, and one was from $R$. rhinobatos (the common guitarfish). Given that $R$. rhinobatos and the type host, Z. schoenleinii, belong to different orders of elasmobranchs, this host record requires verification, ideally by the examination of additional specimens.

The bothridial morphology of $S$. cadenati was not comprehensively described by Euzet (1954). While he noted the presence of 3 transverse septa, Euzet (1954) stated that the bothridia of the specimens he examined were tightly folded and clamped in four scallops. Subsequently, when Euzet and co-authors (Ball et al. 2003) erected the genus Scalithrium Ball, Neifar et Euzet, 2003, for species of Rhinebothrium that lack a median longitudinal septum, they concluded that the scolex morphology of $S$. cadenati was too poorly known to allow them to confidently place it in their new genus at that time.

The work conducted here enabled comprehensive characterisation of the bothridial morphology of $S$. cadenati for the first time. A fourth, less muscular transverse septum (Figs. 12B, 13) lies posterior to the three transverse septa noted by Euzet (1954), and this reduced transverse septum is crossed by some, but not all, non-medial longitudinal septa (Fig. 12B). We believe the scalloped appearance in the posterior part of the bothridium of specimens with folded bothridia noted by Euzet (1954) is due to the presence of these non-medial longitudinal septa.

This redescription also provides additional data on the reproductive morphology and microthrix distribution patterns of this species. Some measurements reported by Euzet (1954) suggest that his specimens of $S$. cadenati were somewhat larger than those examined here. For example, Euzet's (1954) specimens were 4-6 mm long in total length and possessed 13-16 proglottids, whereas the specimens examined here were 1.04-1.77 mm long and possessed 5-7 proglottids. In spite of these differences, we believe that the specimens we obtained for the current study are conspecific with those examined by Euzet (1954), based on the illustrations he provided, and considering that that the specimens we used for this study are from the same host, and within $11 \mathrm{~km}$ of the type locality.

The bothridia of $S$. cadenati are unlike any previously described Stillabothrium species in that they possess septa that differ in thickness. In $S$. ashleyae, $S$. davidcynthiaorum, S. campbelli, S. hyphantoseptum and S. jeanfortiae, all transverse and longitudinal septa appear uniform in thickness. In $S$. cadenati the 3 anteriormost transverse septa are thicker than the fourth transverse septa and the longitudinal septa (Fig. 12B).

Stillabothrium cadenati can also be distinguished from each of its five congeners in its conspicuously different proglottid morphology. Unlike those of its congeners, the genital atrium in $S$. cadenati has convoluted walls that are more muscular in appearance (compare Fig. 12C with 

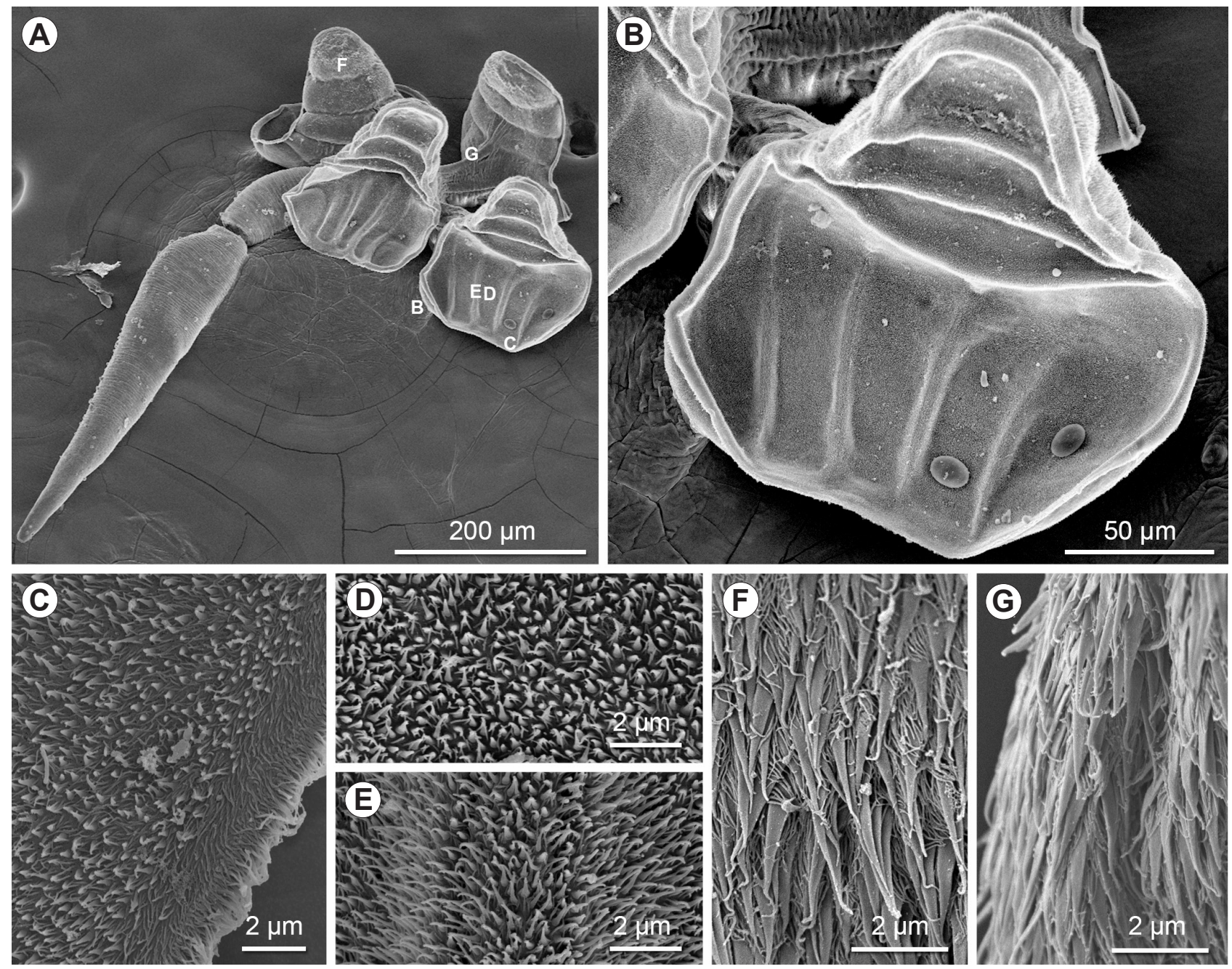

Fig. 14. Scanning electron micrographs of Stillabothrium cadenati (Euzet, 1954) comb. n. from Zanobatus schoenleinii (Müller et Henle). A - scolex, letters indicate locations of other SEMs; B - bothridium; C - distal bothridial surface at rim; D - distal bothridial surface within loculus; $\mathbf{E}$ - distal bothridial surface within septa; $\mathbf{F}$ - proximal bothridial surface; $\mathbf{G}$ - strobila.

Figs. 2C, 4C, 6C, 8C, 10C), and the genital pore is located more anteriorly in S. cadenati (64-73\% of proglottid length from proglottid posterior margin) than it is in S. ashleyae, S. davidcynthiaorum, S. campbelli, S. hyphantoseptum and S. jeanfortiae (35-46\%, 42-54\%, 41-55\%, 50-61\% and $42-$ $56 \%$, respectively). In $S$. cadenati, the vitellarium (Fig. 12C) occurs along the length of the ovary, whereas in $S$. ashleyae, S. davidcynthiaorum, S. campbelli, S. hyphantoseptum and $S$. jeanfortiae, the vitelline columns are interrupted by the ovary (Figs. 2C, 4C, 6C, 8C, 10C). The cirrus sac is relatively larger in $S$. cadenati when compared to its 5 congeners (compare Fig. 12C to Figs. 2C, 4C, 6C, 8C, 10C), and reaches a greater length $(103-171 \mu \mathrm{m} v s$ 28-38 $\mu \mathrm{m}, 32-45 \mu \mathrm{m}$, 45-90 $\mu \mathrm{m}, 52-79 \mu \mathrm{m}$ and $80-87 \mu \mathrm{m}$, respectively).

Stillabothrium cadenati is the only species of the genus reported from the Atlantic Ocean. Specimens that appear to represent at least two additional species of Stillabothrium were encountered in stingrays of the genus Fontitrygon Last, Naylor et Manjaji-Matsumoto over the course of survey work in Senegal. These remain to be examined in detail.
Four specimens of $S$. cadenati were included in the phylogenetic analysis (Fig. 1, Table 1). One of the four specimens (LRP 3924) was previously included in the analysis of Healy et al. (2009) as 'Rhinebothriinae New genus 3 cadenati'.

Stillabothrium amuletum (Butler, 1987) Healy et Reyda comb. n.

Figs. 1, 15

ZooBank number for species:

urn:1sid:zoobank.org: act:DFCD1070-9190-4890-ADEE-5474390DB2BF

Synonym: Anthobothrium amuletum Butler, 1987.

In formal synonyms: Rhinebothriinae New genus 3 sp. n. 7 of Healy et al. (2009), Caira et al. (2014), Ruhnke et al. (2015), Marques and Caira (2016).

Type and only known host: Glaucostegus typus [Anonymous (Bennett)], Giant shovelnose ray (Rhinopristiformes: Rhinobatidae) (= Rhinobatos armatus).

Type locality: Moreton Bay, Northern Territory, Australia. Additional locality: Fog Bay, Timor Sea (Indian Ocean) off Dundee Beach (1245'33"S; $\left.130^{\circ} 21^{\prime} 7^{\prime \prime} E\right)$, Queensland, Australia (AU-56). 


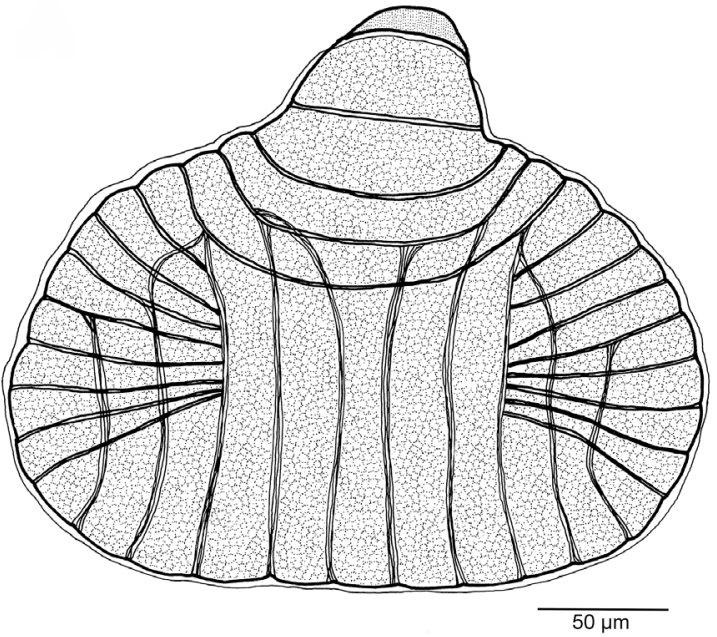

Fig. 15. Line drawing of bothridium of the holotype (QM GL4621) of Stillabothrium amuletum (Butler, 1987) comb. n. from Glaucostegus typus [Anonymous (Bennett)].

Site of Infection: Spiral intestine.

Specimens examined: AU-56, QM GL4621 (holotype), GL4622 (paratype).

Remarks. Butler (1987) provided a comprehensive description of this species, which included scanning electron micrographs and drawings, and represents the only treatment of this species, to date. Although examination of the holotype for the present study confirmed many of Butler's (1987) observations, it refuted some of her observations, and revealed additional details missing from the original description. According to Butler (1987), the anterior region of the bothridia lack transverse septa. However, at least 4 transverse septa are visible in the anterior region of the scolex of this holotype (Fig. 15). These septa, and other septa not described by Butler (1987), are best visible using differential interference contrast microscopy (DIC). Examination of additional material of this species and, ideally, histological sections of the scolex, would be very useful in determining the exact number and extent of the septa (and the loculi) in this species. Not stated in the description, but visible in the holotype, are the following features: the vas deferens joins the cirrus sac at the middle of its anterior margin; the genital atrium has internally convoluted margins; when at least partially expanded with spermatozoa, the vas deferens extends from between the anterior lobes of the ovary to the level of the recurvature of the vagina.

The morphology of the ovary, posterior vitelline follicles and posterior part of the uterus as drawn by Butler (1987) differ from that observed in the terminal proglottid of the holotype: the ovary is tetralobed and H-shaped; vitellarium is interrupted at the level of the ovary and some vitelline follicles are present in the lateral margins of the proglottid, posterior to the ovary; uterus extends posterior to the ovary.

This species possesses transverse septa and non-medial longitudinal septa, as well as other characteristics consistent with its placement in Stillabothrium, such as a posterior row of loculi that are longer than wide (Fig. 15). Thus, this species is herein transferred into this genus as Stillabothrium amuletum comb. $\mathrm{n}$.

Stillabothrium amuletum possesses diagonal septa on the sides of the posterior bothridia, which overlap several longitudinal septa (Fig. 15). This feature distinguishes it from $S$. ashleyae (Fig. 2B) and $S$. davidcynthiaorum (Fig. 4B), and from S. campbelli (Fig. 6B), which possess marginal ( $S$. ashleyae and $S$. davidcynthiaorum) or diagonal (S. campbelli) septa that abut but do not overlap longitudinal septa, and from $S$. hyphantoseptum (Fig. 8B), S. jeanfortiae (Fig. 10B) and S. cadenati (Fig. 12B) which each lack marginal or diagonal septa.

One sequence of Stillabothrium from G. typus, the type host of $S$. amuletum, was included in the phylogenetic analysis in this study (Table 1, Fig. 1). It was from Healy et al. (2009), who referred to it as 'Rhinebothriinae New genus 3 sp. n. 7'.

\section{DISCUSSION}

The integration of morphological and molecular data facilitated species delimitation in the present study. The molecular data were especially helpful in delimiting Stillabothrium ashleyae and S. davidcynthiaorum. Stillabothrium davidcynthiaorum and $S$. ashleyae possess relatively similar bothridial morphologies (i.e. three loculi in the anterior region and longitudinal and marginal loculi in the posterior region; see Fig. 1). These species also have similar proglottid anatomies and are sympatric at least in part in that both occur off Mukah in Malaysian Borneo. These two species differ, however, in the number of longitudinal loculi and septa (eight longitudinal septa in S. ashleyae vs ten longitudinal septa in $S$. davidcynthiaorum).

The molecular data provided support for our hypothesis that the variation in number of longitudinal septa is interspecific rather than intraspecific. The three specimens of $S$. ashleyae that were sequenced, all of which were from the same host individual, had identical sequences. The seven specimens of $S$. davidcynthiaorum that were sequenced formed a clade in which no two individuals differed by more than two bp. The clade of $S$. ashleyae was the sister clade to $S$. davidcynthiaorum (Fig. 1) and the members of the two clades differed from each other by $15-19 \mathrm{bp}$.

The relatively relaxed degree of host specificity seen in S. davidcynthiaorum, which appears to parasitise four (species of Himantura is unusual for a rhinebothriidean species. Such a relatively relaxed pattern of host specificity contrasts a widely demonstrated pattern of strict host specificity in rhinebothriideans and other elasmobranch cestodes in which cestode species typically occur in only a single host species. This is termed an oioxenous level of host specificity (sensu Euzet and Combes 1980) and has been demonstrated in many (Williams 1964, Caira and Jensen 2001, 2014, Jensen 2005, Tyler 2006, Ruhnke et al. 2015) but not all (Palm and Caira 2008, Reyda and Marques 2011) elasmobranch cestode species.

To examine this observation in detail, we included specimens morphologically consistent with $S$. davidcynthiaorum from all four potential host species in the molecular analyses and multiple specimens from each host species 

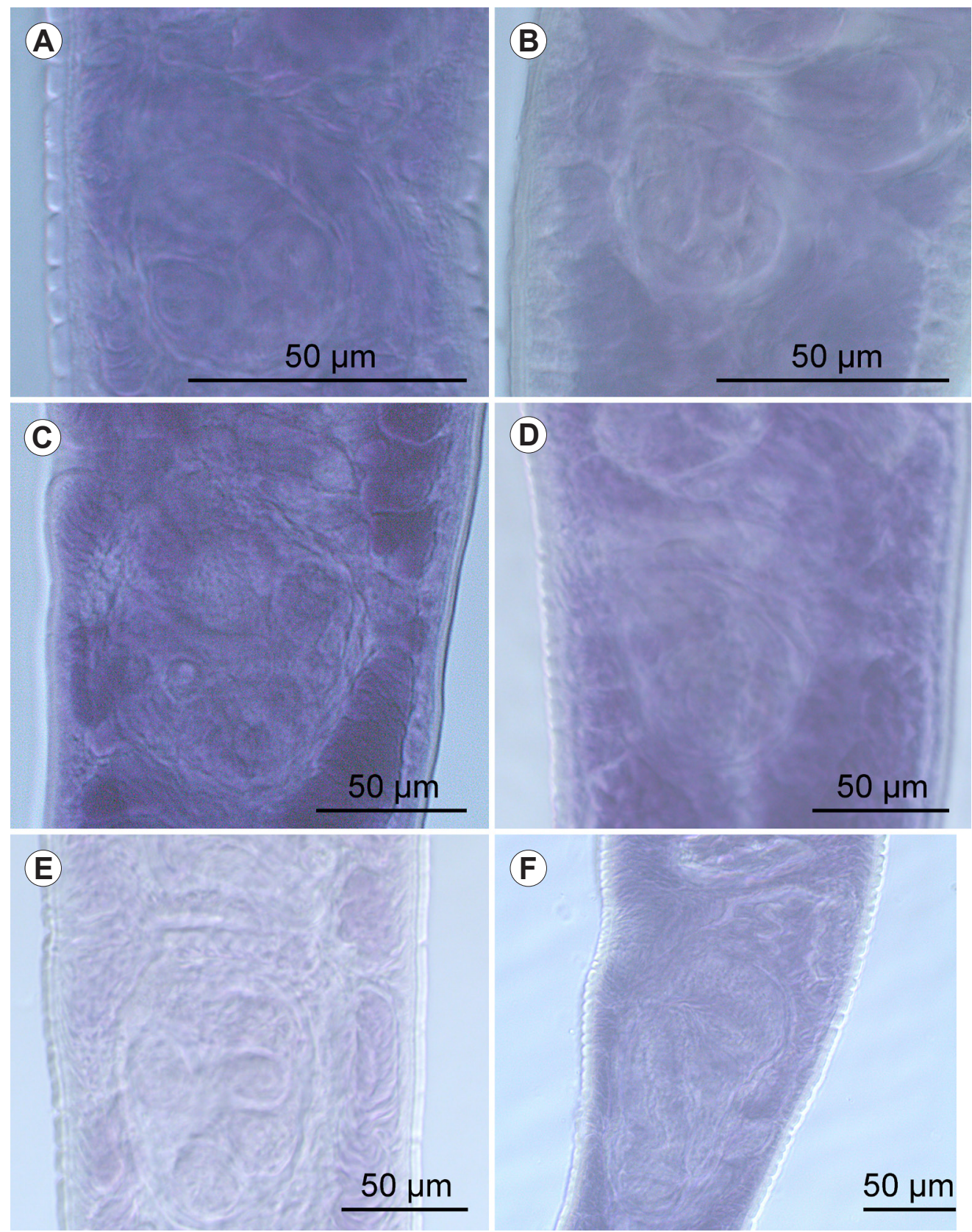

Fig. 16. Light micrographs of terminal genitalia of Stillabothrium species, each with genital pore oriented left. A - Stillabothrium ashleyae sp. n. from Dasyatis biasa (Last, White et Naylor); B - Stillabothrium davidcynthiaorum sp. n. from Himantura gerrardi (Gray); C - Stillabothrium campbelli sp. n. from Himantura cf. pastinacoides; D - Stillabothrium hyphantoseptum sp. n. from Pastinachus solocirostris Last, Manjaji et Yearsley; E - Stillabothrium jeanfortiae sp. n. from Himantura australis Last, White et Naylor; F - Stillabothrium cadenati comb. n. from Zanobatus schoenleinii (Müller et Henle).

were examined in detail morphologically. However, examination of nine specimens from $H$. uarnak 3, six specimens from $H$. gerrardi and 17 specimens from $H$. heterura revealed no clear pattern of anatomical variation beyond the fact that specimens from $H$. heterura were generally smaller $(0.6-1.1 \mathrm{~mm} ; \mathrm{n}=15)$ than those from $H$. gerrardi $(1.0-1.6 \mathrm{~mm} ; \mathrm{n}=6)$ and H. uarnak $3(1.4-2.6 \mathrm{~mm} ; \mathrm{n}=9)$. That variation was ultimately considered to represent intra-specific variation; all specimens, regardless of host species, possessed the key feature of $S$. davidcynthiaorum, i.e. 10 longitudinal septa (and 11 longitudinal loculi) on the posterior bothridia. The molecular data supported this result that given across host species, specimens of $S$. $d a$ vidcynthiaorum differed by no more than two bp.

Host specificity in $S$. ashleyae, S. campbelli, S. jeanfortiae, $S$. hyphantoseptum and $S$. amuletum was much more strict and also much more in line with that seen in other non-trypanorhynch orders of elasmobranch-hosted cestodes (see Caira and Jensen 2014), for each was found to parasitise only a single host species. Host specificity in $S$. cadenati is also slightly more relaxed in that is has been reported from two species, Zanobatus schoenleinii and $R h$ - 
inobatos rhinobatos, both in Senegal. However, its occurrence in the latter species requires verification considering that only a single specimen was encountered in that host.

Beyond their possession of transverse septa and an even number of longitudinal septa, the bothridia across species of Stillabothrium vary greatly in the septal arrangement. Stillabothrium jeanfortiae could be viewed as having the simplest bothridial morphology in that it possesses only transverse septa in the anterior region and only longitudinal septa in the posterior region, and the two types of septa do not overlap. The bothridia of the other six described species are more complicated in that they possess additional features with respect to septa. Four of the other six described species, all of which are from Clade 2, each possess other septa in addition to transverse and longitudinal septa (Fig. 1); in S. ashleyae, S. davidcynthiaorum, S. campbel$l i$ and $S$. amuletum the longitudinal primary loculi on the left and right side are divided by additional marginal or diagonal septa into subloculi. Species also vary in whether septa overlap one another. Stillabothrium campbelli, S. hyphantoseptum, $S$. cadenati and $S$. amuletum each possess longitudinal septa that overlap transverse septa.

The proglottid anatomy also varies greatly among species of Stillabothrium. The size of the cirrus sac relative to proglottid width differs among species (Fig. 16) from relatively small in $S$. ashleyae and $S$. davidcynthiaorum (Figs. 2C, 4C) to relatively large in $S$. cadenati and $S$. amuletum (Fig. 12C and fig. 22 in Butler 1987). The vagina is strongly recurved in $S$. cadenati and $S$. amuletum (Fig. 12C and fig. 22 in Butler 1987), whereas those of the other five species are not. In S. hyphantoseptum, S. cadenati and $S$. amuletum the uterus extends to the posterior margin of the proglottid (Figs. 8C, 12C), while the uterus in each of the other four species extends posteriorly only to the level of the ovarian isthmus. The extent to which the columns of vitelline follicles are interrupted by the ovary also varies. In all but one species the vitelline columns are mostly or entirely interrupted by the ovary (Figs. 2C, 4C, 6C, 8C, 10C). The exception is $S$. cadenati (Fig. 12C), which bears columns that are not interrupted by the ovary.

The morphological features shared by all species of Stillabothrium constitute a very short list. The bothridia of the seven described as well as the three undescribed members of the genus included in the molecular analysis conducted here (i.e. Stillabothrium sp. n. 1, Stillabothrium sp. n. 2 and Stillabothrium sp. n. 4) possess one conspicuous key feature that could be considered a synapomorphy for the genus. In all 10 species, the longitudinal septa in the posterior portion of bothridia are vertically oriented (i.e. longer than wide) and are even, rather than odd, in number. There is one other feature of the scolex that is potentially possessed by all 10 members of the genus. The six Stillabothrium species observed with SEM here (i.e. S. ashleyae, S. davidcynthiaorum, S. campbelli, S. hyphantoseptum, S. jeanfortiae and $S$. cadenati) possess a limited distribution of coniform spinitriches on the proximal bothridial surfaces, though the extent varies. Additional SEM work is needed to verify whether this feature is possessed by the other four species of Stillabothrium included in the molecular analysis.

There is no question that species diversity in Stillabothrium is substantially greater than that characterised here. To begin, as mentioned above, this study included three species (Stillabothrium sp. n. 1, Stillabothrium sp. n. 2, and Stillabothrium sp. n. 4) which await formal study. Two of those are from Senegal, Stillabothrium sp. n. 1 and Stillabothrium sp. n. 2, each parasitising Fontitrygon margaritella (Compagno et Roberts). The voucher specimens of each of those two species (LRP 3898 and LRP 3899 , respectively) reveal that the scoleces of both display variations on bothridial septa configuration that are entirely unlike those described here. There is also at least one additional species of Stillabothirum from Australia, Stillabothrium sp. n. 4, from Himantura astra Last, Manjaji-Matsumoto et Pogonoski. Study of additional specimens acquired during our survey work also suggest that there is additional species diversity of Stillabothrium. As noted in the Remarks sections of the descriptions of S. ashleyae, S. davidcynthiaorum, S. campbelli and S. jeanfortiae, additional specimens from other host species with similar bothridial morphologies to those respective species were encountered here. Those specimens may represent new species, but they await further study. Finally, given that the stingray genus Himantura, the host genus for five of the ten Stillabothrium species in our analysis, is comprised of over 50 species, it seems likely that additional survey work on species of Himantura previously unexamined for cestodes will result in the discovery of other, potentially many, new species of Stillabothrium.

Stillabothrium is a member of the globally distributed family Escherbothriidae. The two genera in the family, Escherbothrium and Stillabothrium, possess vertically oriented septa and loculi in the posterior region of the bothridia. The results of the analysis of Ruhnke et al. (2015) revealed a sister group relationship between the species referred to as Escherbothrium sp., collected from Urotrygon aspidura Jordan et Gilbert from the Pacific Ocean off Costa Rica and Stillabothrium species (referred to in their study as Rhinebothriinae New genus 3). However, the two genera have intriguingly different distributions. Escherbothrium molinae Berman et Brooks, 1994 and the species of Escherbothrium included by Ruhnke et al. (2015) are both from the Pacific coast of Costa Rica (i.e. the Western Hemisphere). In spite of extensive recent survey work in the Western Hemisphere in recent years, no species of Stillabothrium has been encountered there. Rather, the seven described species of Stillabothrium, as well as the multiple undescribed species, are all from the Eastern Hemisphere, specifically the Indo-Pacific and eastern Atlantic. Thus the family Escherbothriidae consists of a clade of species of Escherbothrium from the Western Hemisphere, and a clade of species of Stillabothrium from the Eastern Hemisphere.

Ruhnke et al. (2015) stated that a remaining problematic issue for the diagnosis of the family Escherbothriidae is whether only some, or all, species of the group possess an apical sucker. All evidence suggests that both known spe- 
cies of Escherbothrium have an apical sucker (Berman and Brooks 1994, Ruhnke et al. 2015). This, however, does not appear to be the case for Stillabothrium. Instead, all evidence suggests that the anteriormost feature of the bothridia is a loculus, rather than a sucker. In general this structure is somewhat triangular, rather than round. We see no structural evidence to suggest that the anteriormost loculus differs from any of the other loculi in the anterior region of bothridium. For example, in cross section the musculature of the anteriormost transverse septum and the second transverse septum of $S$. cadenati have the same appearance (compare ATS in Fig. 13 with the transverse septum below it).

Phyllobothrium biacetabulatum Yamaguti, 1960, described from Rhinobatos schlegelii Müller et Henle from the Inland Sea of Japan by Yamaguti (1960), is a rhinebothriidean that potentially belongs within the genus Stillabothrium, but a lack of information on this species prevents its transfer to Stillabothrium at this time. In his monograph on the Phyllobothriidae, Ruhnke (2011) considered Phyllobothrium biacetabulatum as incertae sedis owing to its lack of conforming to the features of the family. In fact, this species has several features that are consistent with the diagnosis of Stillabothrium. The description and accompanying micrographs of Yamaguti (1960) clearly show that each of the bothridia of this species is stalked and divided into an anterior and a posterior region, with the anterior region bearing two transverse septa and the posterior region bearing "about 40 elongate loculi," (Yamaguti 1960, p. 42). Furthermore, its testes do not extend posterior to the cirrus sac, and the vas deferens enters the cirrus sac on its anterior margin close to the genital pore. Those features are sufficient to support formal placement of $P$. biacetabulatum within the Rhinebothriidea as we have done here. Unfortunately, the description is ambiguous with regard to whether or not a medial longitudinal septum is present in the posterior region of the bothridia. It is this feature that distinguishes Stillabothrium from Escherbothrium and from New genus 2 and New genus 4 of Healy et al. (2009). Phyllobothrium biacetabulatum, however, must remain incertae sedis with regard to its generic placement at this time, until further study and examine of type specimens.

Parallel to keeping pace with the growth in knowledge of cestode species diversity over the last two or so decades, is a growth in the knowledge of elasmobranch species diversity, with many new species being discovered and/or recognised in recent years (Naylor et al. 2012b, Last et al. 2016). This has implications for our study. We report seven species of Stillabothrium from a total of 11 elasmobranch species, and we note additional Stillabothrium specimens and additional potential species from six other elasmobranch species. Among these 17 species of elasmobranchs, two were considered by Naylor et al. (2012b) either to be unique undescribed species (and hence given numerical designations) or to be species that may be new to science but whose identifications require further study (and hence were given 'cf.' designations): H. cf. pastinacoides, and H. uarnak 3. Both of these species are from Borneo, a region considered to be a centre of elasmobranch endemism and diversification (Naylor et al. 2012b, White and Last 2012). We have employed the Naylor et al. (2012b) designations here so that as these host species are formally described in the future, the elasmobranch collection information provided here can be linked to the Global Cestode Database (Caira et al. 2012) where the ray names would be updated.

We suggest that future studies of Stillabothrium continue to use a combination of molecular and morphological data for species delimitation and understanding of host specificity and that, whenever possible, those analyses include multiple specimens of each putative Stillabothrium species. This has also been done in species of other rhinebothriidean genera, such as Rhinebothrium (see Reyda and Marques 2011). Considering the importance of bothridial septa in defining species of Stillabothrium and given that septa can vary in their visibility (e.g. the fourth transverse septum of $S$. cadenati was not visible in all specimens; compare Figs. 12A and 12B), we also emphasise the importance of using DIC (differential interference contrast) microscopy in future studies of the genus. In addition, we caution against using bothridial shape in contracted specimens in delineating Stillabothrium species.

Author Contributions. C.J. Healy performed some of the field work and wrote a portion of the text, prepared some of the specimens that were used in this study, prepared several SEMs and two line drawings, and provided a conceptual framework for the new genus. F.B. Reyda verified the morphological measurements, wrote most of the text and prepared all of the figures. T.R. Ruhnke and A.R. Haslach conducted the molecular work and phylogenetic analyses, and T.R. Ruhnke also performed some of the field work. R.S. Russell prepared some of the specimens and assisted with species comparisons, as did K.S. Herzog, who generated the description of $S$. hyphantoseptum (including taking measurements, preparing SEMs and line drawings, and writing text) with M.P. Bergman and F.B. Reyda. D.D. Willsey and F.B. Reyda generated the description of $S$. ashleyae (including taking measurements, preparing sections, SEMs and line drawings, and writing text); A.L. Daigler and F.B. Reyda generated the description (including taking measurements, preparing sections, SEMs and line drawings, and writing text) of S. davidcynthiaorum; I. Delgado, E.A. Dedrick and F.B. Reyda generated the description (including taking measurements, preparing sections, SEMs and line drawings, and writing text) of S. campbelli; K.S. Forti. T.L. Aprill and F.B. Reyda generated the description (including taking measurements, preparing sections, SEMs and line drawings, and writing text) of $S$. jeanfortiae; C.J. Healy and F.B. Reyda redescribed S. cadenati and prepared the new combination of $S$. amuletum.

Acknowledgements. We are grateful to Janine Caira (University of Connecticut, Storrs, Connecticut), Kirsten Jensen (University of Kansas, Lawrence, Kansas) and colleagues for conducting the fieldwork and providing all of the specimens for this study. This work was partially supported with funds from National Science Foundation (NSF) grants, including Biotic Surveys and Inventories (BS\&I) grants (DEB Nos. 0103640, 0542846), Partnership for Enhancing Expertise in Taxonomy (PEET) grant (DEB No. 0118882), a Planetary Biodiversity Inventory (PBI) collaborative grant (DEB Nos. 0818696 and 0818823), NSF REU stipends to MPB, KSH, and RSR, and a Field Stations and Marine Laboratories (FSML) grant (DBI No. 1034744). Partial funding for this 
study was also provided by grants from the State University of New York College at Oneonta Research Foundation awarded to FBR, ALD, ID, KSF, KSH, RSR, and DDW. This work was performed in part at the Biosciences Electron Microscopy Facility of the University of Connecticut (NSF grant No. 1126100). CJH acknowledges Dale Calder (Royal Ontario Museum, Toronto, Ontario) for use of a microscope. The authors thank the anonymous reviewers of this manuscript for their helpful comments.

\section{REFERENCES}

Ball D., Neifar L., Euzet L. 2003: [Description of Scalithrium n. gen. (Cestoda, Tetraphyllidea), with Scalithrium minimum (Van Beneden, 1850) n. comb., a parasite of Dasyatis pastinaca (Elasmobranchii, Dasyatidae), as type species] Parasite 10: 3137. (In French.)

Berman R., Brooks D.R. 1994: Escherbothrium molinae n. gen et n. sp. (Eucestoda: Tetraphyllidea: Triloculariinae) in Urotrygon chilensis (Chondrichthyes: Myliobatiformes: Urolophidae) from the Gulf of Nicoya, Costa Rica. J. Parasitol. 80: 775-780.

Butler S.A. 1987: Taxonomy of some tetraphyllidean cestodes from elasmobranch fishes. Aust. J. Zool. 35: 343-371.

CAIRA J.N., JENSEN K. 2001: An investigation of the co-evolutionary relationships between onchobothriid tapeworms and their elasmobranch hosts. Int. J. Parasitol. 31: 960-975.

Caira J.N., Jensen K. 2014: A digest of elasmobranch tapeworms. J. Parasitol. 100: 373-391.

Caira J.N., Jensen K., Barbeau E. 2012: Global Cestode Database. University of Connecticut, Storrs, CT, USA. World Wide Web electronic publication, http://www.tapewormdb.uconn.edu, $12 / 2015$.

Caira J.N., Jensen K., Waeschenbach A., Olson P.D., LitTLEWOOD D.T.J. 2014: Orders out of chaos - molecular phylogenetics reveals the complexity of shark and stingray tapeworm relationships. Int. J. Parasitol. 44: 55-73.

Chervy L. 2009: Unified terminology for cestode microtriches: a proposal from the International Workshops on Cestode Systematics in 2002-2008. Folia Parasitol. 56: 199-230.

Cielocha J.J., Jensen K., Caira J.N. 2014: Floriparicapitus, a new genus of lecanicephalidean tapeworm (Cestoda) from sawfishes (Pristidae) and guitarfishes (Rhinobatidae) in the Indo-West Pacific. J. Parasitol. 100: 485-499.

Clopton R.E. 2004: Standard nomenclature and metrics of plane shapes for use in gregarine taxonomy. Comp. Parasitol. 71: 130140 .

Euzet L. 1954: Parasites de poisons de mer ouest africains récoltés par J. Cadenat. I. Cestodes tetraphylllides de sélaciens. (Note préliminaire). Bull. Ins. Fran. d'Afrique Noire. Série A 16: 126138.

Euzet L., Combes C. 1980: Les problémes de l'espéce chez les animaus parasites. Mem. S. Zool. F. 3: 239-285.

Eyring K.L. Healy C.J., Reyda F.B. 2012: A new genus and species of cestode (Rhinebothriidea) from Mobula kuhlii (Rajiformes: Mobulidae) from Malaysian Borneo. J. Parasitol. 98: 584-591

Healy C.J. 2006: A revision of selected Tetraphyllidea (Cestoda) Caulobothrium, Rhabdotobothrium, Rhinebothrium, Scalithrium, and Spongiobothrium. PhD Dissertation, University of Connecticut, Storrs, Connecticut, $382 \mathrm{pp}$.

Healy C.J., Caira J.N., Jensen K., Webster B.L., Littlewood, D.T.J. 2009: Proposal for a new tapeworm order, Rhinebothriidea. Int. J. Parasitol. 39: 497-511.

ICZN 1999: International Code of Zoological Nomenclature, Fourth Edition. The International Trust for Zoological Nomenclature, London, $306 \mathrm{pp}$.

IVANov V.A., CAIRA J.N. 2012: Description of three new species of Echinobothrium (Cestoda: Diphyllidea) from Indo-Pacific elasmobranchs of the genus Glaucostegus (Rajiformes: Rhinobatidae). J. Parasitol. 98: 365-377.

Jensen K. 2005: Tapeworms of Elasmobranchs (Part I). A Monograph on the Lecanicephalidea (Platyhelminthes, Cestoda). Bull. Univ. Nebr. State Mus. 18 (i-viii), 241 pp.

Jensen K., Russell S.L. 2014: Seussapex, a new genus of lecanicephalidean tapeworm (Platyhelminthes: Cestoda) from the Folia Parasitologica 2016, 63: 038 stingray genus Himantura (Myliobatiformes: Dasyatidae) in the Indo-West Pacific with investigation of mode of attachment. Folia Parasitol. 61: 231-241.

Jensen K., Mojica K.R., Caira J.N. 2014: A new genus and two new species of lecanicephalidean tapeworms from the striped panray, Zanobatus schoenleinii (Rhinopristiformes: Zanobatidae), off Senegal. Folia Parasitol. 61: 432-440.

Kuchta R., Scholz T., Brabec J., Bray R.A. 2008: Suppression of the tapeworm order Pseudophyllidea (Platyhelminthes: Eucestoda) and the proposal of two new orders, Bothriocephalidea and Diphyllobothriidea. Int. J. Parasitol. 38: 49-55.

Last P.R., Manjaji B. M., Yearsley G.K. 2005: Pastinachus solocirostris sp. nov., a new species of stingray (Elasmobranchii: Myliobatiformes) from the Indo-Malay Archipelago. Zootaxa 1040: 1-16.

Last P.R., Naylor G., Manjaji-Matsumoto B.M. 2016: A revised classification of the family Dasyatidae (Chondrichthyes: Myliobatiformes) based on new morphological insights. Zootaxa 4139: 345-368

Marques F.P.L., Caira J.N. 2016: Pararhinebothroides - neither the sister taxon of Rhinebothroides nor a valid genus. J. Parasitol. 102: 249-259.

Mojica K.R., Jensen K., Caira J.N. 2013: Revision of Anteropora (Cestoda: Lecanicephalidea) and descriptions of five new species from stingrays (Myliobatiformes: Dasyatidae) in Borneo. Raffles Bull. Zool. 61: 491-506.

Naylor G., Caira J.N., Jensen K., Rosana K.A., Straube N., LAKNER C. 2012a: Elasmobranch phylogeny: a mitochondrial estimate based on 595 species. In: J.C. Carrier, J.A. Musick and M.R. Heithaus (Eds.), Biology of Sharks and Their Relatives. CRC Press, Boca Raton, pp. 31-56.

Naylor G., Caira J.N., Jensen K., Rosana K.A., White W.T. 2012b: A DNA sequence-based approach to the identification of shark and ray species and its implications for global elasmobranch diversity and parasitology. Bull. Am. Mus. Nat. Hist. 367: 215-240.

Palm H.W., Caira J.N. 2008: Host specificity of adult versus larval cestodes of the elasmobranch tapeworm order Trypanorhyncha. Int. J. Parasitol. 38: 381-388.

Pleijel R., Jondelius U., Norlinder E., Nygeren A., Oxelman B., Schander C., Sundberg P., Thollesson M. 2008: Phylogenies without roots? A plea for the use of vouchers in molecular phylogenetic studies. Mol. Phylogenet. Evol. 48: 369-371.

REYDA F.B., CAIRA J.N. 2006: Five new species of Acanthobothrium (Cestoda: Tetraphyllidea) from Himantura uarnacoides (Myliobatiformes: Dasyatidae) in Malaysian Borneo. Comp. Parasitol. 73: 49-71.

Reyda F.B., Marques F.P.L. 2011: Diversification and species boundaries of Rhinebothrium (Cestoda; Rhinebothriidea) in South American freshwater stingrays (Batoidea; Potamotrygonidae). PLoS ONE 6: e22604.

Ronquist F., Huelsenbeck J.P. 2003: MRBAYES 3: Bayesian phylogenetic inference under mixed models. Bioinformatics. 19: 1572-1574.

Ruhnke T.R. 2011: Tapeworms of Elasmobranchs (Part III). A Monograph on the Phyllobothriidae (Platyhelminthes, Cestoda). Bull. Univ. Nebr. State Mus. 25 (i-xii), 208 pp.

Ruhnke T.R., CAIRa J.N., Cox A. 2015: The cestode order Rhinebothriidea no longer family-less: a molecular phylogenetic investigation with erection of two new families and description of eight new species of Anthocephalum. Zootaxa 3904: 051-081.

Schaeffner B.C., Beveridge I. 2012: Cavearhynchus, a new genus of tapeworm (Cestoda: Trypanorhyncha: Pterobothriidae) Page 27 of 28 
from Himantura lobistoma Manjaji-Matsumoto \& Last, 2006 (Rajiformes) off Borneo, and new records of species of Pterobothrium Diesing, 1850. Syst. Parasitol. 82: 147-166.

Schaeffner B.C., Beveridge I. 2014: The trypanorhynch cestode fauna of Borneo. Zootaxa 3900: 021-049.

Swofford D.L. 2000: PAUP*: Phylogenetic Analysis Using Parsimony, Version 4.0b, Sinauer Assoc., Sunderland, Massachusetts.

Twohig M.E., Caira J.N., Fyler C.A. 2008: Two new cestode species from the dwarf whipray, Himantura walga (Batoidea: Dasyatidae), from Borneo, with comments on site and mode of attachment. J. Parasitol. 94: 1118-1127.
Tyler G.A. 2006: Tapeworms of Elasmobranchs (Part II). A Monograph on the Diphyllidea (Platyhelminthes, Cestoda). Bull. Univ. Nebr. State Mus. 20 (i-xiii), 142 pp.

White W.T., Last P.R. 2012. A review of the taxonomy of chondrichthyan fishes: a modern perspective. J. Fish Biol. 80: 901917.

Williams H. 1964: Some new and little known cestodes from Australian elasmobranches with a brief discussion on their possible use in problems of host taxonomy. Parasitology 54: 737-748.

Yamaguti S. 1960: Studies on the helminth fauna of Japan. Part 56. Cestodes of fishes, III. Publ. Seto Marine Biol. Lab. 8: 41-50.

Cite this article as: Reyda F.B., Healy C.J., Haslach A.R., Ruhnke T.R., Aprill T.L., Bergman M.P., Daigler A.L., Dedrick E.A., Delgado I., Forti K.S., Herzog K.S., Russell R.S., Willsey D.D. 2016: A new genus of rhinebothriidean cestodes from batoid elasmobranchs, with the description of five new species and transfer of two species. Folia Parasitol. 63: 038. 